\title{
SPAIS =
}

\section{On the Edge of 'No Man's Land' \\ Chronic Emergency in Myanmar \\ Mark Duffield \\ Department of Politics, University of Bristol \\ (C) Mark Duffield}

\section{School of Sociology, Politics, and International Studies, University of Bristol Working Paper No. 01-08}

Mark Duffield is Professor of Development Politics in the Department of Politics at the University of Bristol. During the latter part of the 1980s, he was Oxfam's Country Representative for Sudan. He has completed extensive research and consultancy work for a variety of UN agencies, NGOs and donor governments in the fields of humanitarian intervention, internal war and social reconstruction. Professor Duffield has published widely in these fields and his book, Global Governance and the New Wars: The Merger of Development and Security (2001) is currently in its fourth impression. His current research continues to explore the linkages between humanitarianism, development and security. His new book, Development, Security and Unending War: Governing the World of Peoples, was published by Polity Press in 2007. 


\title{
On the Edge of 'No Man's Land': Chronic Emergency in Myanmar
}

\begin{abstract}
:
Myanmar, or Burma as it is still usually known, remains little understood in the West. Existing knowledge mostly comes from the plight of the refugees living on the Thai border and the violence of the military regime that put them there. Rather than reworking this familiar territory, this working paper looks at the chronic humanitarian emergency within Myanmar. This is analysed in relation to the existence of a colonially-derived design of power operating through emergency and the exercise of arbitrary personal authority. The dynamics of totalitarian rule are examined and, in particular, how people and communities are wantonly exposed to danger and the irrelevance of their being. When coupled with the absence of an effective system of social welfare, the result is a chronic emergency that now grips Myanmar as a whole. The working paper also describes how aid agencies, including local NGOs, operate inside Myanmar. Despite being a difficult working environment, through an innovative application of the humanitarian principles of neutrality, impartiality and transparency, aid agencies have succeeded creating a space for independent action. They have, for example, altered local social dynamics and improved the precarious levels of protection enjoyed by many communities. Regarding policy, rather than strengthening capacity as such, concerns should focus more on how to push back, contain or domesticate rule through emergency and the exercise of arbitrary person power.
\end{abstract}




\section{CONTENTS}

Preface

Acronyms

Executive Summary

1. Introduction

2. From Exception to Anomaly

2.1 A structural aid orphan

2.2 Blurring inside/outside

2.3 A restricted aid architecture

3. The Nature of Power

3.1 Separating development and underdevelopment

3.2 Colonialism and emergency

3.3 Governing through uncertainty

\section{Chronic Emergency}

4.1 The political economy of information

4.2 The contours of a chronic emergency

4.2.1 The September 2007 unrest

4.2.2 Ethnic coexistence

4.2.3 The absence of public welfare

\section{Operating Environment}

5.1 Below the radar

5.2 The possibility of protection

5.3 The problem with development

6. Conclusion

6.1 Containing power rather than reconstructing states

6.2 From human security to social security 


\section{ACRONYMS}

CAP Consolidated Appeals Process CBO

Community-Based Organisation CERF

Central Emergency Response Fund

CIDA Canadian International Development Agency

DFID Department for International Development

FAO Food and Agricultural Organisation

IASC Inter-Agency Standing Committee

ILO International Labour Office

INGO International Non-Governmental Organisation

KIO Kachin Independence Organisation

LNGO Local Non-Governmental Organisation

MNPD Ministry of Nation Planning and Development

MoU Memorandum of Understanding

NC National Convention

PDC Peace and Development Council

SLORC State Law and Order Restoration Council

SPDC State Peace and Development Council

UN RC/HC United Nations Resident and Humanitarian Coordinator

UNCT United Nation's Country Team

UNDOC United Nations Office on Drugs and Crime

UNDP United Nations Development Programme

UNHCR United Nations High Commission for Refugees

UNICEF United Nations Children's Fund

USDA Union Solidarity and Development Association

WHO World Health Organisation 


\section{PREFACE}

This report is not an evaluation of the international aid operation in Myanmar. Rather, it is an attempt to put the operating environment there into a wider historical and geographical perspective. In particular, it addresses the nature of power through the experiences of the people who, in different ways, and on a daily basis, confront its realities. In order for them not to fall victim to this power, all identities, organisations and locations have been withheld. At the same time, however, my debts are many and extensive. I would like to take this opportunity to thank warmly those many people that helped me by giving freely of their time, support and generosity of spirit. Without this, I would not have been able to complete this work.

The report was commissioned by the former UN HC/RC, Yangon, with the support of UNOCHA, New York. It is, however, a completely independent enquiry and does not reflect UN policy or position. Any errors or misconceptions are entirely my own.

Mark Duffield

Sedgley

United Kingdom 


\section{EXECUTIVE SUMMARY}

\section{Introduction}

Myanmar has been associated with war and ethnic conflict for over half a century. This war is now as much global as it is local. Besides physical violence, it also embraces a battle of ideas, identities and values. A defining feature of this internationalized battlespace is its polarized nature. Within this global arena a militarised dictatorship - the SPDC - confronts a range of external political activists and international human rights lobby groups. The territory upon which these warring parties have pitched their tents, and on whose behalf they claim to speak, are the peoples of Myanmar. Myanmar - or Burma - is an internationalised battlespace where the peoples' multiple masters have established competing regimes of truth and legitimacy. Between and around these defining poles lie a medley of different actors government bureaucracies, ceasefire groups, non-ceasefire groups, businessmen, aid agencies and donor governments - that are either trying to coerce, tax or dispossess the people, or else, protect, educate and better them. As a means of escaping the dead end of the polarising discourse that defines Myanmar/Burma, this report explores the chronic emergency there from the perspective of the humanitarian principles of neutrality, impartiality and transparency.

Given this polarised battlespace, humanitarian principles have been applied more widely in Myanmar than is usual. From the local to the international they have been used to prise apart, as it were, the population's competing masters to expose the chronic emergency beneath their feet. At all levels of engagement, the principles of neutrality, impartiality and transparency, have been used to push back the boundaries of arbitrary personal power that have long been the root cause of Myanmar's chronic emergency. The aim is not to speak on behalf of the communities concerned, but to create a space of possibilities. While nothing is given within this space - least of all development - it can be used as a starting point for an alternative policy framework. Rather than reconstructing state capacity, for example, the concern is more to push back, contain or domesticate a particular and discrete design of power that governs through uncertainty and fear. At the same time, if development is to occupy the space that humanitarianism is able to create, development has to move beyond its restricted diet of basic needs and the stasis of self-reliance; it has to become far more aspirational.

\section{From Exception to Anomaly}

In terms of the operational conditions in which aid agencies work, Myanmar is a difficult environment. The default setting of the government is one of suspicion and restriction. However, compared to other parts of the global South, especially zones of crisis and instability, these conditions are not exceptional. At the same time, like other crisis regions, Myanmar is also an aid orphan. Despite its poor social welfare indictors, it receives relatively little international assistance. Strategic engagements like Iraq and Afghanistan excepted, since the end of the Cold War, international aid has tended to concentrate in countries that are judged to already possess a good policy environment. This aid as investment approach has meant that many non-strategic but exceptionally poor and politically volatile countries have been left trailing in the beneficiary league tables. While not exceptional, Myanmar is however an anomaly. Besides lying in a region of relative growth, comparable features such as a difficult working environment and aid paucity are refracted through a polarising lens of Western sanctions and a climate of political isolation. While not practiced regionally - nor directly diminishing the amount of international humanitarian 
assistance received - the impact of this restrictive climate is noticeable in relation to the institutional aid architecture within Myanmar.

Since the early 1990s, one effect of the external lobby groups, especially, in the USA and $\mathrm{UK}$, has been to produce an incomplete roster of in-country UN agencies. At the same time, some of these, including UNDP, ILO and UNODC, operate on restricted mandates. As a consequence of being unable to practice its conventional capacity-building activities with government, UNDP, for example, has assumed the form of a large international NGO (INGO). Donor governments represented in Yangon are few and, despite some having large programmes, the INGO contingent is also relatively small. In other difficult environments, fragile state policy based on ideas of coherence between aid and politics and forms of shadow alignment with the state have gained ground. Apart from sector specific initiatives, the nature of the state, restrictive environment and fragmented aid architecture in Myanmar have worked against generalising such an approach.

In response to this anomalous situation, the $\mathrm{UN} \mathrm{RC/HC}$ has widened the usual application of humanitarian principles. Albeit from a low starting point, reassurances of neutrality, impartiality and transparency have helped increase the amount of international assistance going to the people of Myanmar. In turn, this has encouraged a significant growth of local NGOs (LNGOs) and community-based organisations (CBOs). Importantly, the knowledge effect of this expansion has begun to challenge the existing polarised discourse. For a couple of decades, Myanmar has been understood as Burma, that is, in terms of the refugee camps in Thailand and the military violence that put them there. Treated in isolation, and using government national welfare indicators as a comparator, the camps came to symbolise the exceptionalism of the regime. The increased aid activity within Myanmar, however, has undermined this paradigm in several ways. Aid agency surveillance has exposed how government statistics exaggerate public wellbeing. At the same time, the borders areas have begun to lose their humanitarian distinctiveness. A more complex picture of a chronic emergency across the whole of Myanmar has emerged. Moreover, in attempting to understand this chronic emergency, rather than confirming conventional wisdom, Myanmar's anomalous position questions its basic assumptions.

\section{The Nature of Power}

Aid policy tends to avoid addressing the nature of power; not only in Myanmar but in crisis states more generally. Weak states, fragile states or even rogue states, for example, are usually treated as if somewhere inside exist the rudiments of a rational Weberian bureaucracy waiting to emerge. Iraq and Afghanistan are graphic examples of this default setting. Policy becomes the isolation and nurturing of these putative seeds. While reassuring in its familiarity, it avoids facing the possibility that, in relation to the West and its underdeveloped borderland at least, two interconnected but generically different forms of bureaucratic administration are in play. A Weberian bureaucracy associated with welfare states and the administration of mass consumer societies and, in distinction, colonial bureaucracy - or colonially-derived bureaucracy - associated with today's post-nationalist states and underdevelopment. These bureaucratic traditions represent two distinct ways of governing human population or life; they reflect two different but interconnected designs of power.

Weberian bureaucracy, for example, operationalises insurance-based compensatory benefit systems and welfare safety-nets covering birth, education, health, employment and pensions. Inclusion within such life-support systems is a formative definition of a developed existence. 
Colonial bureaucracy relates to population very differently and emergences in response to an original problem; how do you govern populations acquired through conquest that are independent of the state in terms of their welfare and social survival? Since the age of discovery, life in the non-Western world has been distinguished from the multiple dependencies that define a civilised existence in terms of its ascribed powers of selfreproduction. It has been experienced as self-reliant in terms of its basic biological, social and economic needs. While having a long genealogy, this assumed ability to be able to survive in the raw, as it were, beyond the insurance-based welfare bureaucracies of mass society, defines an underdeveloped existence.

Colonial bureaucracy governs self-reproducing populations through the ability to arbitrarily suspend the law and declare a state of exception: it governs through holding self-reliant populations on the threshold of emergency. This ability - originally vested in the person of the colonial official - ran from the top to the bottom of the political administration. Coupled with the performative use of violence, that is, not just a way of punishing but also educating a population, colonial bureaucracy governs through the uncertainty over where sovereign power lies and when it might appear; it provides an administrative support for the exercise of arbitrary personal power. Its function is to act upon independent self-reproducing populations, rendering them docile and tributary. Myanmar's military - the Tatmadaw together with the population's other masters have inherited this design of power. The military-based SPDC regime has taken over and deepened a classic totalitarian dual state. In other words, a state divided between the normal organs and institutions of law and government, and an over-riding prerogative state that can suspend the law, govern by decree and the exercise of arbitrary personal power. Hannah Arendt first pointed out the design overlaps between colonial administration and the great fascist and communist totalitarian regimes of the twentieth century. From the standpoint of the 1950s, however, Arendt was unable to see another future inheritor: the post-nationalist states that would eventually emerge from the rubble of empire and the struggles against colonialism.

In Myanmar, the prerogative military state within SPDC regime dominates the normal organs of government. The regime governs through the uncertainty of where the arbitrary power of the leadership lies and when it will appear. Uncertainty and fear flows from the top to the bottom of the bureaucracy. It produces a hierarchical follow the leader culture of government that stifles innovation. While able to discipline subordinates, it is non-the-less a weak design of power. The self-discipline involved is not widely internalised; it is a design of power it has to be constantly renewed through performative mechanisms. In this respect, a primary requirement is a permanent enemy. Important here has been the recasting of the racially divided society of colonial Burma into the ethnically divided post-nationalist state of Myanmar. Within such a society, every sign of opposition or dissent, whatever the cause or issue, is transformed into the work of political agitators and a threat to society as a whole. While the use of performative of violence is ancillary to this task, administration generally becomes a theatre of government. Mass demonstrations of loyalty are regularly choreographed. Despite the inherent design weakness of colonially derived bureaucracies, however, they have significant power effects; not least of these it the ability to constantly expose self-reliant populations to the risks and contingencies of their existence.

\section{Chronic Emergency}

Progress does not necessarily have a positive impact upon social welfare. Free trade, for example, can drive out local industry and crafts while, at the same time, eroding land tenure 
and lowering dietary standards. In this context, chronic emergency can be defined as the exposure of a population to risk and uncertainty by the exercise of arbitrary personal power in the absence of an effective compensatory insurance or welfare system. While colonial bureaucracies are renowned for compiling statistics, they collected them primarily for administrative and security considerations, not to measure the social welfare of subject peoples. The SPDC regime has continued this tradition. Indeed, in common with other zones of crisis, it is the relatively recent emergence of the international humanitarian system that has introduced the practice of monitoring human wellbeing. Post-nationalist states have usually experienced such activity as a threat to their sovereign legitimacy. In Myanmar there is an absence of systematic information on the changing social ecology of survival and resistance among its subject peoples. The nature of the chronic emergency in Myanmar has to be derived from the snapshots that its periodic breakdowns provide.

Myanmar presents itself as a post-nationalist medley of different ethnic groups each pursuing their own interests and agendas. The peoples of the central Divisions and outer ethnic states, however, do have one thing in common: in different ways and for different ends they are similarly exposed to the exercise of arbitrary personal power. In September 2007, for example, monks led a series of demonstrations in the towns of central Myanmar protesting an irresponsible government hike in petrol costs that immediately eroded already precarious living standards. Among Myanmar's predominant Burman (or Bamar) population, the monkhood has long functioned as an informal system of public welfare. Boys given up to monasteries, for example, relieve some of the pressures on poor households. Prior to the September unrest, monasteries had been inundated with new entrants and had begun turning away applicants. At the same time, the public alms upon which monks themselves are dependent had begun to dry up. The September demonstrations began as a largely spontaneous and leaderless response to the widespread social malaise. Many of the young monks involved were themselves its direct product. As the unrest gained momentum this initial focus on social breakdown was overlain with the more familiar language of polarisation. This suited the SPDC, enabling it to resume business as usual: hunt the ringleaders and mobilise society against the external enemy. For a short period, however, the September unrest revealed the extent of chronic humanitarian emergency within Myanmar.

One effect of business as usual, is that the unrest in the central Divisions did not translate into the ethnic States. Despite the peoples of Myanmar being similarly subject to the exercise of arbitrary personal power, the unrest was largely seen as an inter-Burman affair. At the same time, however, how such power is manifest in the ethnic States has its own characteristics. The ceasefire agreements, for example, have recast the balance of power between the military, township authorities, ceasefire groups, non-ceasefire groups, businessmen and aid agencies. It is in the context of these ceasefires, moreover, that the ambiguity of war and peace, especially, the relationship between progress and social welfare can be seen. Compared to the isolation enjoyed by some during the war years, peace has exposed populations to new forms of risk. Commercial exploitation and land dispossession, for example, is now common. Road construction is a good example of this ambiguity. The road network has noticeably expanded over the past decade or so and has brought new commercial interests into otherwise isolated rural areas. Forced labour levied from local communities has been a significant factor in this expansion. In the absence of a formal tax system, once constructed these roads have become a new technology of tribute. Through organised checkpoints, the peoples multiple masters have established an effective means of taxing circulation. From a liberal perspective roads should open up markets, boost trade and increase social welfare. In Myanmar, they have encouraged dispossession and 
environmentally damaging forms of production while taxing the efforts of the local peasantry off the roads.

Although the chronic emergency that exists across Myanmar has different modalities, they interconnect. In all places, peoples experienced as essentially self-reliant are exposed to arbitrary exactions and demands. Such unchecked impositions present households and communities with the challenge of constant adaptation. Important here is labour migration. The social malaise in the central Divisions and dispossession in the ethnic States, for example, come face to face in the process of circulation. Circuits of national and transnational migration intersect in nodal points of Myanmar's jade and gold mines, commercial plantations and logging ventures. These unregulated circuits are the vectors of Mynmar's HIV/AIDS epidemic. Apart from the constant exposure to risk, the chronic emergency is magnified by the absence of a compensatory public welfare system. Not only is government provision grossly underfunded, fragmented and largely confined to the towns under its control, the existing services has been subject to a process of de facto privatisation. Starved of government funding, the rudimentary health and education services are characterised by widespread practices of user fees, cost sharing or community subventions. As on the roads, the poor are priced out of the system.

\section{The Operating Environment}

The assumption that the peoples are essentially self-reliant is a factor common to all of Myanmar's multiple masters; even the aid agencies. Indeed, the latter have the support of self-reliance as their fundamental aim. From a global perspective, however, self-reliance has been impossible since the end of the nineteenth century when the formation of the global market brought the great peasantries of African and Asia into direct competition with the farmers of the American prairie and Russian steppe. The result, documented in the case of colonial Burma, has been the decline in the social welfare of indigenous peoples. In charting this decline globally, the formation of an international humanitarian system is important. A recognisable, internationally integrated system emerged during the early $1970 \mathrm{~s}$. While this can be interpreted from a humanistic perspective as evidence of a growing international enlightenment, more practically, it signalled that the crisis of self-reliance had reached a global tipping point and become permanent. Since this period, the international humanitarian system has expanded and deepened in concert with this permanent emergency. Indeed, this system constitutes a form of international insurance of last resort for the world's non-insured populations.

Reflecting Myanmar's anomalous status, the humanitarian principles of neutrality, impartiality and transparency have been applied more widely than normal. At the level of aid coordination, for example, they have been deployed by the UN RC/HC as a buffer between the parties to the polarised political discourse that defines Myanmar/Burma. This manoeuvre has helped increase the amount of humanitarian assistance inside Myanmar and consequently supported the significant growth of LNGOs and CBOs. This growth, moreover, has also been underpinned by the locally-informed application of humanitarian principles; in this instance, in relation to the restrictive threat of arbitrary personal power. The term often encountered to describe the space of aid agency activity in Myanmar is below the radar. This term, however, since it implies that something is hidden, is misleading. Rather than concealment, effectively using this space is based upon openness, engagement and visibility. In pushing back the exercise of arbitrary personal power, protection works through the modalities of openness. Generally speaking, international agencies are able to protect to 
some extent LNGOs and these, in turn, are able to protect CBOs, and so on. In utilising this protection, LNGOs and CBOs, in particular, have expanded locally through the nuanced practice of transparency. Using the community-based project as the starting point, arbitrary personal power is disarmed and neutralised through its engagement and cooption. Local commanders, township authorities and ceasefire groups, for example, are kept informed, invited to launch ceremonies and, if appropriate, drafted onto committees. Through such networking and alliance building, protection is extended to local communities. In addressing the root cause of chronic emergency - unchecked personal power - this expansion of local level protection has been a major if fragile achievement.

\section{Conclusion}

While humanitarian action can create a space of possibilities, the limitation relates to how development agencies have used that space. The problem is what lies above the radar, so to speak, not below it. It relates to the stock NGO capacity building and micro-finance projects aiming to re-establish a putative self-reliance. In terms of the relief to development continuum, the problem is not the relief component, which does provide an insurance of last resort and limited forms of local protection, the main problem is the bankruptcy of the basic needs/self-reliant model of development. The challenge in Myanmar, as elsewhere, is to be more ambitious and imaginative in filling the space of possibilities that humanitarian action can create: development has to become aspirational. The issue is not so much state reconstruction, the challenge is more to use juridical, legal and constitutional measures to contain a colonially-derived design of power. At the same time, while basic needs and selfreliance have a transitional importance, there is a need to move from human security to social security. That is, to search for more universalistic and effective solutions to the risks and uncertainties of existence for non-insured populations living beyond the borders of mass consumer society. 


\section{INTRODUCTION}

The title this report - On the Edge of 'No Man's Land' - came from a phrase used by a UN official attempting to describe the anomalous position of Myanmar in the world of international aid. He meant to convey a sense of difference reflected in a range of factors including an incomplete UN roster, the restricted mandates of some agencies, challenging and uncertain operating conditions, and the feeling of a chronic emergency only partially glimpsed. The idea of a no man's land, however, also has a more literal meaning. To tease this out we need to imagine a country ruled by a military dictatorship that has entrenched opponents. Nearly half a century of conflict has produced a society in which both the state and many of its opponents are highly militarised (Smith 2007). While reaching an uneasy and ambiguous peace with the majority of these, some have been driven out and across Myanmar's borders. A state of war continues to exist between the dictatorship and these external opponents. While actual fighting is now geographically restricted to a few border zones, the war itself has broadened. It is a war of political ideas, identities and values that is being fought on a regional and international stage.

While widening in scope, war remains a site of imitation and self-recognition (van Creveld 1991). On pain of defeat, not only do the methods and organisation of competing armies come to resemble each other, war also offers a reflecting surface where opponents become self-aware and assured of their own values, whatever they may be. In our imagined Myanmar, political exiles measure their democratic credentials against the repressive and violent acts of the state. Their liberal supporters use these same acts to call for sanctions against the regime and to deny it a legitimate place in the world of states. For its part, the military government - the State Peace and Development Council (SPDC) - experiences in these manoeuvres the very reasons for its fight for "...a new, peaceful, modern and developed nation" (USDA 2007: 1); a fight that it presents as constantly being undermined by the destructive isolation imposed upon it from outside.

Such wars of ideas and identities not only contain processes of mutual self-awareness but, perhaps because of this, they also often tend towards self-perpetuating forms of polarised political discourse. One can see this, for example, in the Palestinian and Israeli war, or in Rwanda, in relation to the conflicting Hutu and Tutsi views of history. The 'Hutu perspective', for example, regards the Tutsi as foreign invaders that have historically exploited Hutu farmers. Conversely, a 'Tutsi perspective' argues that Hutu and Tutsi are all Rwandans and that it was colonial rule that divided them against each other (Van Hoyweghen 2004). The main characteristic of such closed discourse is that as soon as one speaks, regardless of intentions, one is classified and placed in one camp or the other. For several decades - if not longer - Myanmar has been characterised by such a polarised discourse (Taylor 1995: 46-7). Even the name of the country has become part of a classificatory process. In 1989 the State Law and Order Restoration Council (SLORC), the forerunner of the SPDC, as part of a wider process of renaming, changed the colonially imposed 'Burma' to what it argued was a more authentic 'Myanmar'. While this change has been accepted by the county's regional neighbours, and to a large extent internally, many political opponents, advocacy groups and Western governments pointedly retain the name Burma as an invocation of the continuing struggle for liberal values (see Callahan 2007: ix-xi). The danger of polarised discourse, however, is that even a name carries the risk of instant classification as friend or foe. 
In escaping this political dead end, the report situates itself on a terrain that is common to all parties, even declared enemies. That common denominator is the people of Myanmar/Burma on whose behalf, interests, rights and future welfare all parties compete and seek to speak. It is this foundation of people - the disconnected mass of rural communities, migrants, urban workers, IDPs and refugees - upon which competing regimes of truth have been erected. At the same time, it is here that one also finds an unexpected complicity between opponents. Despite the government's hubris, for example, it has singularly failed to provide for the welfare of its people. In fact, its actions constantly expose its citizens to danger and risk. At the same time, it is deeply suspicious of aid agencies including attempts to collect demographic information in support of their activities. Such information, with its fragmented disclosures of chronic poverty, vulnerability and dispossession, constantly threatens to undermine the state's self-proclaimed role as the guardian of the people.

At the same time, the external opposition and advocacy groups are suspicious of the same agencies (IDC 2007). Their concerns however are different. They are anxious that welfare support should not benefit the state; either directly through resource transfer or capacity building, or indirectly in terms of reflected legitimacy. Despite these differences, in one thing at least, the regime and the advocacy groups are similar. That is, their wish for "... the departure of the assistance community from Myanmar" (Petrie 2005: 1). At the same time, new demographic information is slowly exposing the chronic emergency within the country. As a result, the competition between 'inside' and 'outside' agencies for donor funding is increasing. The "insurgency paradigm" that for decades has defined Burma externally, as it were, in terms of the plight of its refugees, is also beginning to see its relevance slip because of the changes underway (South 2007b).

The peoples of Myanmar have multiple masters. If the state and its external opponents constitute two extremes, then between and around these poles is a medley of other actors: military commanders, township authorities, ceasefire groups, non-ceasefire groups, businessmen, aid agencies and donor governments. All of these actors are in different ways addressing or impacting upon that changing social ecology of survival and resistance that is euphemistically referred to as the community. They are variously attempting to discipline, tax or dispossess the peoples of Myanmar or, conversely, trying to protect, educate and better them. This social ecology of people and population is the no man's land of this report. It is a terrain that is constantly being fought over, claimed and reclaimed in the name of truth and legitimacy. Modern humanitarianism emerged in the blood of the battlefield and the suffering that armies inflict on each other. The humanitarian principles of neutrality, impartiality and transparency have long been practiced as a way of creating a space, so to speak, where a common humanity can be held above the tumult of war. In Myanmar however the battlespace has expanded to embrace the soft-power of political ideas and identities, and internationalised to include the technologies of sanctions and isolation; all of which impact on the social ecology of communities and their survival.

As a result of this expansion, a case exists for widening the scope of humanitarian principles. A militarised society confronted by a complex international environment suggests that humanitarian principles should be applied at all levels of engagement, from the local through the national to the international. In asserting such principles, the aim is not to speak on behalf of Myanmar's dispossessed and oppressed peoples. By defending a common humanity, the intention is to push back the boundaries of arbitrary power and uncontrolled force that have long been the root cause of Burma's and now Myanmar's chronic emergency. When it is successful, and a case can be made in Myanmar for this, humanitarian action can 
create a space of possibilities. What fills that space however is ultimately up to the people themselves - with or without the help of the international community.

Section two examines the anomalous position of Myanmar. As well as being similar to other difficult aid environments, the actions of external lobby groups have had a significant impact upon the aid architecture within the country. Section Three looks at the nature of political power in Myanmar. In particular, how a colonially-derived design of governance through arbitrary personal rule has been reincarnated within the Tatmadaw's SPDC regime. Section Four examines the chronic emergency in Myanmar. Especially how militarised sovereignty a design shared between multiple actors - undermines social welfare; a power effect that is magnified by the absence of an effective system of public welfare. Section Five is concerned with the operating environment. In particular, how humanitarian principles have been deployed at the levels of aid and community action to create a protective space. Section Six, the conclusion, draws this analysis together and suggests that attention be directed to the two main causes of Myanmar's chronic emergency; namely, the exercise of unchecked personal power and the absence of a compensating system of public welfare.

\section{FROM EXCEPTION TO ANOMALY}

\subsection{A structural aid orphan}

This report attempts to put the humanitarian crisis within Myanmar into a wider international context. While this comparative theme runs throughout, some initial positioning is required. A central argument is that while Myanmar is a difficult aid environment, it is in no way exceptional. It is better to think of Myanmar as an anomaly which, among other things, challenges conventional wisdom. A useful starting point is to consider Myanmar's position as an 'aid orphan'. Contrary to what one would expect given its poor development indicators, for example, on average more than $75 \%$ of household income is spent on food and fewer than $50 \%$ of children complete primary education (UNCT 2007), Myanmar receives significantly less international assistance than many other apparently more fortunate countries. This anomalous position is accentuated by Myanmar's geographical setting in a region of relative growth and - while not equitably distributed - rising prosperity. Since the 1980s, Myanmar's welfare indicators have been declining compared to its neighbours. Its GDP, for example, is less than half that of Bangladesh and Cambodia (Ibid). Agricultural production has stagnated while international trade has declined. In 1987, in a move to secure debt relief, the UN designated Burma a Least Developed Country (LDC). As a mark of the hardening international attitude towards the regime, this has not been forthcoming. Myanmar's orphan status, however, cannot be explained purely in relation to political considerations. To the contrary, there is an important structural element.

Since the end of the Cold War, if one excludes those countries that are strategically important, such as Pakistan, Afghanistan and Iraq and consume enormous amounts of aid, international assistance has tended to concentrate in what are judged good policy environments. These countries have adopted liberal economic prescriptions and the state has sufficient capacity to pursue a poverty reduction strategy through budgetary means. In Africa typical examples include Tanzanian, Mozambique, Uganda and Ghana (Harrison 2004). The result of this conservative aid as investment bias has been to leave some 40 to 50 countries, from Latin America through Africa to South East Asia, as comparative aid orphans. Like Myanmar, these countries lack effective welfare systems and are difficult political environments for aid agencies to work in. While containing less than a fifth of the world's 
population, these states account for a much greater proportion of global poverty and its associated ills (Leader and Colenso 2005: 9). Despite high levels of social deprivation, compared to the aid world's 'good performers', such countries receive proportionally very little international assistance. From a development as security perspective, however, in recent years this imbalance has attracted increasing concern and forms of the basis of fragile state policy (DFID 2005).

\subsection{Blurring of inside/outside}

While Myanmar's condition as an aid orphan has structural considerations, the activities of external lobby groups that have queried the giving of aid cannot be ignored. The insurgency paradigm in which Myanmar exists as Burma, that is, through the lens of Thai refugee camps and the acts of military repression that created these flows, can be traced to the major army offensives of the 1980s and the solidarity work of NGOs operating along the Thai/Burma border. Many of the agencies and individuals involved had already been doing similar work along the Thai/Cambodia border. However, in the twilight years of the Cold War, the 1980s was the golden age of the non-governmental 'cross-border' operation. NGO solidarity work was also taking place, for example, across the Pakistan/Afghanistan and Sudan/Ethiopia borders. Compared to humanitarian ideas of neutrality and impartiality, this work typically involved identifying with and a willingness to work through the leadership and elites of particular refugee and internal opposition groups. It was also a time when international NGOs had a greater distance from donor governments. This was sometimes reflected in their solidarity work being at odds with Western foreign policy. Constantly rejuvenated by the political repression within Myanmar, by the mid 1990s a highly polarised political situation had emerged in which the stock call of aid groups working on the border - then more numerous than the agencies on the inside - was for tough international sanctions. On a more personal level, those few aid workers or agencies then tentatively attempting to operate inside Myanmar were frequently branded sell-outs, even fascists, and with whom dialogue was ruled out.

Over the past decade, however, a number of factors have been slowly undermining the insurgency paradigm. For some years, the humanitarian situation inside Myanmar has been equated with plight of displaced peoples and refugees on its borders. When NGOs operating from Thailand have surveyed these populations, and then compared their condition with the Myanmar government's official welfare statistics, a picture of acute but localised humanitarian need emerges (TBBC 2004). Since the late 1990s, however, partly in response to the growing ceasefire agreements within Myanmar's ethnic States, the number of aid agencies, including international NGOs (INGOs), local NGOs (LNGOs) and communitybased organisations (CBOs) operating internally has markedly increased (South 2007a). This opening up of Myanmar has both questioned the veracity of government statistics and, at the same time, begun to establish a picture of more generalised need. In the central dry zone, for example, landlessness, under-employment, out-migration and food insecurity is rife. In some areas, child malnutrition is reported to be comparable, if not higher, than border averages. Some communities are receiving humanitarian assistance in the form of food-for-work projects. At the same time, agencies working from inside Myanmar that have gained access to conflict affected populations along the eastern border (the so-called black zones) report conditions similar to areas that are open. In both "...the situation is neither good or bad, its just difficult". The border areas moreover, especially the eastern borders which function as an extension of the Chinese and Thai economies, are widely held to be more economically dynamic than the rest of Myanmar. In terms of telecommunications, for example, these areas 
are much better served than central Myanmar. Many of the youth from these regions have been attracted into Thailand as migrant labourers. The resulting vacuum has pulled many internal migrants from the central dry zone into the eastern towns. Given that Thailand has recently started a programme of $3^{\text {rd }}$ country refugee settlement, for some this has highlighted the ambiguity of the refugee question. Despite the repressive government, is seeking refugee status now just one of a number of strategies for escaping Myanmar's chronic emergency?

As a result of a growing exposure of the conditions within Myanmar and, at the same time, evidence that work is possible without necessarily strengthening the state, the former polarisation has begun to soften, at least, with regard to operational agencies. The 3D Fund, established in 2006 to address HIV/AIDS, malaria and TB, has been important in this respect. Although earlier HIV/AIDS initiatives had existed, the 3D Fund was specifically set up on fragile state principles, that is, to 'work with the government not through the government'. While the Ministry of Health has a coordinating role, no funds or capacity building goes to government departments and actual implementation is carried out through a combination of UN agencies, INGOs and LNGOs. Encouraged by such initiatives, for several years there has been a growing dialogue and increasing transparency between agencies working inside and outside the country. In December 2006, for example, under UN auspices groups met for the first time in Bangkok to discuss mutual operating conditions. A number of sectoral meetings have subsequently taken place. With regard to operational agencies working on the Thai side of the border, few now insist on a total aid boycott, and there is a wider acceptance that welfare support can be separated from implicit or explicit support for the government. In other words, a climate of cautious engagement appears to be emerging.

\subsection{A restricted aid architecture}

In contrast, however, the situation among some advocacy groups is different. Generally speaking, they have become more institutionalised and internationalised. Compared to their forebears in the 1980s, today's lobbyists, especially in America and Britain, are more in tune with the liberal interventionism that has shaped Western foreign policy in the post-Cold War years. For some observers, however, the increased lobbyist's access to populist politicians playing to a domestic audience comes at a price. There is a tendency to present a simplified $\mathrm{good} / \mathrm{bad}$ view of what is happening in Myanmar and, at the same time, downplay the complex internal changes that have taken place since the violent domestic repression of 1988 . The growth of LNGOs and CBOs, for example, is often dismissed on the grounds that they are not genuine civil society groups because they do not openly confront the military regime. While this may be true, it significantly underestimates the impact on local power relations and dynamics, including the enhancing of community protection, which such groups have had. This is discussed in more detail in section 5.2.

The lobby groups have supported the international trade, investment and financial sanctions first imposed against Myanmar by the by the EU in 1996 and the USA in 1998. These sanctions have been strengthened on several occasions, including in response to the state repression of the demonstrations in September 2007. The relation of these sanctions to Myanmar's aid orphan status is not straightforward or direct. The closure of the HIV/AIDS Global Fund in 2005, for example, has been attributed to the activities of American lobby groups (ICG 2006). However, while the sanctions are widely regarded as having a negative impact on social welfare (Select Committee 2007: 3-4), the EU's Common Position, aware of this possibility, exempts humanitarian assistance and allows support for programmes relating to health, education and poverty reduction. Indeed, the EU is one of the main donors in these 
areas. At the same time, as discussed above, Myanmar's status as an aid orphan is shared by other states. While aid parsimony as such is not easily connected to the existence of economic sanctions (which in any case are not widely recognised by Myanmar's regional neighbours), the restrictive political climate associated with the sanctions regime has had an impact. This is more directly reflected in the externally imposed limited mandates of some UN agencies and the fragmented donor presence within Myanmar.

Regarding the UN system in relation to difficult environments more generally, since the end of the 1990s, the 'integrated mission' has been the preferred operating template (Eide et al. 2005). Briefly stated, through a robust system of coordination, the integrated mission is designed to increase policy coherence between the UN's political and aid missions. The UN system in Myanmar, however, is incomplete let alone being integrated in this sense. The DPA, IMF and World Bank, for example, are formally absent and, while increasing its administrative support, UNOCHA is based in Bangkok. At the same time, largely reflecting the different structures of their boards and their susceptibility to political pressure, several $\mathrm{UN}$ agencies operate with restricted mandates. Following the international concern over the government's failure to recognise the 1990 election, the UNDP, for example, has had a restricted mandate since 1993. Under pressure from the US State Department, this precludes it engaging in any governance or capacity building work with the regime. At the same time, there is not a lot of support in New York for the humanitarian agenda that it has subsequently developed. The ILO also provides no capacity building and is mainly restricted to working on the question of forced labour in so far as it relates to the government, local authorities and the army. Importantly, work in the private sector, including the deregulated mining and logging industries, is precluded. UNODC is also prevented by its board from providing any capacity building in relation to law and enforcement in relation to drugs. At the same time, however, several UN agencies, for example, WHO, FAO and UNICEF, have a more 'business as usual' relationship with government counterparts. These agencies usually only work in government controlled areas. UNICEF, however, is subject to greater external pressure to monitor its activities than the other two. When one also considers that WFP and UNHCR both have atypical country programmes, together with the absence of a CAP process for collective funding appeals, one can appreciate the fragmented and restricted UN presence.

While aid has increased since the end of the 1990s, the UNCT has tended to pull in different directions. This has been accentuated by the government's preference to register different agencies under separate ministries. At the same time, owing to the self-imposed isolation of the military regime, the Office of the UN Resident Coordinator in Yangon does not have regular high level engagement with the government. Such contacts have mainly been achieved through the periodic visits of the Secretary General's special representatives. In the past, the spectrum of different relations and board involvement has worked against both effective regional coordination and, more generally, establishing a collective UN position. At the end of 2006, however, the position of the UN Resident Coordinator was expanded to include role of Humanitarian Coordinator. This has created a number of new possibilities. Apart from additional CERF funding, for example, it has allowed an Inter-Agency Standing Committee (IASC) to be formed bringing together INGOs and some donors. At the same time, in response to the government's repression of the September protest, the UNCT took a number of collective steps. These included the setting up of a hot-line where information about the security clampdown could be left anonymously and, importantly, the issuing a collective statement drawing the government's attention to the plight of the people and its limited welfare efforts (UNCT 2007). 
While hesitant and contingent change is underway, the same politically induced fragmentation can be seen in relation to donor governments. Again, there is a spectrum of different comportments. This ranges from DFID, which is in the process of relocating its office from Bangkok to Yangon, to CIDA which reflects the Canadian opposition to internal aid, preferring to concentrate its efforts on the cross-border operation. While the USA and Germany have representatives in Yangon, the main donor governments providing humanitarian and welfare assistance inside Myanmar are the EU, UK, Australia, Japan and Korea. The EU, however, is based in Bangkok, as are the Myanmar representatives of Sweden, Norway, Denmark and Switzerland; the latter group, however, have mainly provided support to border programmes. Wile there are monthly donor meetings in Bangkok, donor meetings in Yangon are only a recent occurrence and are still sporadic. In the light of growing competition between inside and outside agencies for donor funding, several respondents commented negatively on the Yangon/Bangkok split and the need for more effective coordination. In passing, it should be noted, that while the actions of the Chinese, Indian, Bangladeshi and Thai governments are crucial to conditions inside Myanmar, other than ad hoc programmatic contacts, there appears to be no coherent involvement with these governments in Yangon.

Myanmar receives relatively little international assistance relative to its poor development indicators. At the same time, it has a repressive government that is unresponsive, indeed, obstructive regarding the activities of aid agencies. Such factors are not exceptional and are shared with a number of other countries. What is unusual, however, is the degree to which aid has been politicised to the extent of creating a spectrum of conflicting operating preferences and restricted mandates.

\section{THE NATURE OF POWER}

One possible inference from the above discussion is that, providing political objections could be met, Myanmar would benefit from an increase in foreign aid and improved coordination. Regarding economic progress and social welfare, however, it has long been recognised, even in colonial Burma, that the two are not necessarily connected and increases in the former can actually undermine the latter (Furnivall 1948). In the same way, increasing aid or improving agency coordination cannot be simply taken for granted as solving the problems of poverty and insecurity. The anomalous position of Myanmar, especially, how it fits uneasily into preconceived aid categories or recipient conditions, means that it can be used to interrogate conventional wisdom rather than reproduce it. In problematising working with the state, the lobby groups have made it difficult for aid agencies and donor governments simply to adopt a business as usual attitude. In this respect, much of fragile state policy, in seeking to break down capacity building into simplified evolutionary stepping stones (Torres and Anderson 2004), reproduces conventional wisdom. Ineffective, difficult or abusive states are habitually experienced as containing the vestiges of a neutral or rational Weberian bureaucracy. From this perspective, policy seeks to isolate these rational seeds and nurture them into full existence. The suggestion here is that such states, and the power design that animates them, may actually need containing or dismantling rather that developing or reconstructing.

\subsection{Separating development and underdevelopment}

A useful starting point is Mary Callahan's work on Myanmar's emerging political complexes (Callahan 2007). While the majority Burman (or Bamar) population mainly lives within the seven central Divisions, most of Myanmar's ethnic minority groups, or national races, live in 
seven ethnic States that form a loose horseshoe around this centre. Since the ceasefire agreements of the early 1990s, the population in the country's ethnic States can be understood as living under multiple masters. These include the Myanmar army, or Tatmadaw, SPDC authorities, businessmen, merchants, Chinese or Thai resource extractors, aid agencies, NGOs and, not least, the ceasefire groups whose numbers have continued to multiply. The SPDC currently has ceasefire arrangements with over 25 different ethnic forces, with another dozen remaining in armed struggle (Smith, 2007: 2). While the nature of these agreements is varied, Callahan has distinguished three broad patterns according to how the balance of force is played out locally. In the Wa and Kokang territories of Shan State, for example, the SPDC exists in a relation of near devolution of authority "...to networks of former insurgent leaders, traditional leaders, business people, and traders" (Callahan 2007: xiv). In northern Rakhine, Kayah and Karen states, the Tatmadaw and SPDC constitute a dominant and oppressive force of occupation. In Kachin and northern Shan, together with parts of Karen and Mon states, a range of strategic partners “...including ceasefire group leaders, business operators, Union Solidarity and Development Association (USDA) leaders, traders, religious leaders, NGO personnel and government officials" (Ibid) exist in an uneasy coexistence. These three broad typologies - devolution, occupation and coexistence suggest different ways in which dominant groups impact upon and engage with subject peoples. They indicate different combinations of force and competitive power which variously seek to coerce, discipline or dispossess, or else, inculcate, educate or better the subject life encountered.

In this respect, Myanmar's Kachin, Mon or Karen peoples, for example, resemble national races in other countries that are also subject to simultaneous processes of discipline and development; for example, the Dinka and Fur of Sudan, the Oromo of Ethiopia or, for that matter, the Sunni and Shia clans of Iraq. Such peoples - and there are many of them, in fact, there is a world of peoples - have something in common. They are subject to a liberal design of power that relates to them as collective, self-organising and productive entities somehow naturally self-reliant in terms of their basic biological, economic and social needs. The world of peoples is a self-reproducing socio-economic conglomeration and, as such, a source of endless bounty and patronage. This experience is fundamental to the distinction between 'developed' and 'underdeveloped' modalities of existence and emerges with modernity (Duffield 2007). It is well reflected, for example, in Enlightenment views of Natural Man. To paraphrase Rousseau - he drinks from the stream, eats from the tree, sleeps under the same tree, and behold his needs are satisfied. Once a romantic notion, this is now a desperate reality for many.

Western development policy contains an ingrained and formative assumption that the major part of humanity is, to a lesser or greater degree, self-reliant in terms of its basic biological, social and economic needs. It is formative in that it suggests what Michel Foucault (Foucault 2003) would call a biopolitical (as opposed to the more familiar geopolitical) distinction between developed and underdeveloped species-life. A species-life speaks to the collective or aggregate life of a population and is understood in terms of the interventions, specialist knowledge, institutions and compensatory mechanisms that support and promote life, and through their selective operation also allow death. Rather than autonomy and self-reliance, a 'civilised' existence has for a long time been distinguished from an 'uncivilised' one in terms of its multiple and refined dependencies. Today this is reflected, for example, in mass consumer society's dependence on a global division of labour in commodities, trade, finance and labour. Within the developed world - perhaps $20 \%$ of the world's population - life is protected from the contingencies and risks of existence through a variable geometry of 
largely insurance-based social welfare measures. This includes combinations of private and social insurance, together with tax contributions supporting a range of welfare bureaucracies and safety-nets covering birth, education, health, sickness benefit, unemployment and pensions (Wood and Gough 2006). Many of the Kachin, Wa and the Karen, for example, like the Dinka, Fur and Oromo, are 'underdeveloped' because they live in the raw, as it were, not only outside such insurance-based welfare bureaucracies but as though somehow not needing them. Liberal development doctrine has long held that, while basic in its scope, the social ecology of kin and community provides an appropriate and affordable, welfare alternative (Cowen and Shenton 1996).

\subsection{Colonialism and emergency}

Distinguishing 'development' and 'underdevelopment' biopolitically, that is, in terms of how life is both supported and allowed to die is important for several reasons. It brings to the fore in a concrete way the immense challenge of providing adequate social welfare and protection at a global level. It presents this challenge in terms of the contrasting life chances of 'insured' and 'non-insured' existence. As will be discussed in section 5, it also provides a context in which contemporary humanitarian action can be more fully understood. Finally, in a broad sense, it highlights the possibility of contrasting styles, problematics and administrations of government relating to the developed and underdeveloped worlds. In short, it suggests the existence of different governmental bureaucracies and state formations relating to dependent (developed) and autonomous (underdeveloped) species-life respectively. Rather than the seeds of the former being contained in the latter, as it were, the argument here is that we are addressing, in ideal-typical terms, two essentially different and self-contained modes of government (Shenhav and Berda 2007). Rather than the one leading to the other in an evolutionary or stepping-stone sense, these modes of government are constitutive of development and underdevelopment and, if anything, maintain this division. From this perspective, Weberian bureaucracy - classically expressed in the administration of the European welfare state - is the bureaucratic basis of developed or dependent life. Colonial bureaucracy - and its modern post-nationalist derivatives - is the administrative basis of underdeveloped or autonomous non-insured life. Consequently, in attempting to reconstruct fragile states, care has to be taken to avoid recreating another colonially derived administration that, yet again, entrenches the despotic rule of underdevelopment (Duffield 2007).

Colonial bureaucracy is a form of administration well suited to governing life deemed to be self-reproducing and in relation to which the state has no extensive welfare obligations. While colonial rule was justified in terms of establishing the rule of law, since it was an act of conquest, from the outset it was clear to its practioners that law itself would never be sufficient (Hussain 1999). Faced with autonomous populations deemed to be culturally or racially incapable of self-rule, something else was needed. This was the ability to suspend the law and declare a state of emergency; in effect, through martial law to hold a population on the threshold of emergency as a condition of its governance. This ability was typical of colonial bureaucracy generally and connected the Governor General to the isolated District Commissioner. Unlike Weberian bureaucracy, colonial administration emerges as a bureaucratic vehicle for the arbitrary exercise of personal power. The constant uncertainty over where law ends and emergency begins, or when the state will reveal itself, embodies a performative and magical use of violence. Martial law is not a way of punishing more thoroughly or completely, it is a different logic of punishment. It embodies the performative use of violence to achieve a moral or educative effect at the collective level of population. 
Rather than a specific retaliation as such, it is more concerned with the generalised restoration of sovereign rule. The episodic violence and collective punishment is intimately concerned with restoring the "habit of obedience" (Ibid: 114). The performative use of emergency powers emerges as a way of governing autonomous self-reproducing populations. It provides a way of disciplining and changing behaviour, taxing and levying, organising and reorganising. In short, it produces docile and tributary populations. ${ }^{1}$

The nineteenth century annexation of Burma as an appendage of imperial India resulted in a particularly marked form of direct militarised rule (Callahan 2002). A loose typology of administration within the British Empire would have Burma at one extreme with, say, Sudan or Nigeria, with the more liberal practice of indirect rule, at the other. While all these bureaucracies had the ability to suspend the law, faced with widespread resistance (Ni Ni Myint 1983) it was in Burma that emergency formed the over-riding logic of government. By the end of the nineteenth century, the reality of British rule in Burma could be summarised as opening its peoples to the unbridled capitalism of the world market and, reliant upon the Indian Army, pacifying and policing the calamitous outcome. The mechanics of direct rule, including the selective recruitment of Burma's ethnic minorities to the new national army, helped lay the foundations for today's divided Myanmar where a majority Burman 'centre' surrounded by an equally divided 'periphery' of national races (Callahan 2002). The direct rule over the former contrasted with the indirect rule over the latter. While this has echoes with the present disjuncture, a major difference is that the national army or Tatmadaw is now largely Burman in ethnic composition.

J S Furnivall, in his classic study of colonial rule in Burma, Colonial Policy and Practice: A Comparative Study of Burma and Netherlands India (1948), makes no mention, at least directly, of government through emergency. His main focus, given the disastrous effects of British rule, was on how to understand and improve social welfare. Central to his analysis was the concept of a plural society. For Furnivall the superstructure of imported Western laws and business practices was only one aspect of colonial society. The other was its racial mix. This mix not only included the Burmese - which Furnivall tends to treat as one - but importantly, those outside ancillary groups that colonial rule depended upon. While outside merchants were common in the colonial world, Burma again presents itself as an extreme. As well as Chinese traders, as an appendage of imperial India there was - apart from soldiers and police - a significant presence of Indian civil servants and professionals. These groups effectively blocked the Burmese from the offices and professions that colonialism called forth. Furnivall sums up the relations between this racial mix of Europeans, Indians, Chinese and Burmese as being that of a medley "... for they mix but do not combine" (Ibid: 304). Each group holds by its own language and culture and, as individuals, they meet only in the exchanges and transactions of the market-place. In other words, a plural society is one were its different components live side by side but separately "...within the same political unit. Even in the economic sphere there is a division of labour along racial lines" (Ibid).

Furnivall's plural society is not the same as the contemporary understanding of pluralism, that is, a celebration of cultural diversity and tolerance. It is rather a divided society. Improving social welfare depended upon reintegrating Burma's plural society. Nationalism was for Furnivall a force that was capable of doing this (Taylor 1995). For a few years prior

\footnotetext{
${ }^{1}$ Giorgio Agamben (Agamben 2005) has written much in relation to Europe on emergency and the state of exception as a mode of governance. Critics such as Hussain, however, have pointed out that colonial and postnationalist bureaucracy provide a classic demonstration.
} 
to independence in 1948, it seemed that this might be the case. With the immediate eruption of civil war, however, the military and civilian leaders of the time had few options but to once again "....redeploy the colonial security apparatus to hold together a disintegrating country during the formative period of postcolonial state transformation" (Callahan 2002:

535). Tracing its genealogy to colonial bureaucracy, the use of military force and martial law as a means of addressing the consequences of Burma's and now Myanmar's divided society has fated the entire post-independence period.

Established in its present form in 1988, the Tatmadaw government must rank as a classic example of the juridical heritage of colonial bureaucracy. To call it a 'living museum piece', however, understates the changes that have taken place and trivialises the immediacy of its power effects. These effects - the capricious suppression, beatings, curfews, uncertainty and fear - do at least offer the modern time traveller in Myanmar a taste of 'old' Burma. In a review of the fate of Furnivall's plural society, Robert Taylor (Taylor 1995) has suggested that, while independence struck the decisive blow, its last vestiges disappeared with the economic crisis of the 1980s. With the rise of the Tatmadaw regime, however, perhaps one can see not the disappearance of the plural society but its indigenisation and internationalisation. Replacing the colonial racial mix of Europeans, Indians, Chinese and Burmese is the post-nationalist disintegration of the latter category into its multiple ethnic constituencies including Burman (Bamar), Karen (Kayin), Kachin, Mon, Rhakine, Shan, Chin, Wa and Pao. Replacing and supplementing the earlier Europeans, Indians and Chinese, one has a whole new medley of racially defined actors including businessman, tourists and, not least, aid workers, all living and circulating separately with their own interests and agendas. In confronting this divided post-nationalist ethnic landscape, the SPDC has taken the heritage of colonial bureaucracy to its logical extremes: through the performative use of martial law and government through decree it has fashioned a state that is little more than a security mechanism. It is a state that has lost touch with its founding in law and is incapable of experiencing dissent - whatever its form - as anything but a threat to its claim to defend society as a whole. However, an important aspect of the indigenisation of the plural society has been the generalisation of militarised forms of authority and government through emergency (Smith 2007). Besides the state, the multiple masters of Myanmar's population the ceasefire groups, non-ceasefire groups, private companies and aid agencies - to varying degrees share or exploit the same problematic of power.

In different ways, these parties still regard the populations they confront through a colonial lens of self-reliance or self-reproduction in terms of basic biological, economic and social requirements. The multiple masters that define Myanmar's emerging political complexes are variously exploiting this self-reliance or else, in the name of development, attempting to reinforce it. In consequence, this dependence upon population has both reinforced Burma's 'conflict trap' of ethnic wars (Ibid) and simultaneously strengthened the fragmented nature of Myanmar's post-nationalist plural society. As will be argued in the next section, governance through the arbitrary exercise of personal power, with its constant exposure of people to danger and risk, also underpins Myanmar's chronic emergency. At the same time, it provides a key to understanding the nature of humanitarian space. In concluding this section, in relation to the SPDC, some of the characteristics of this power are sketched in more detail.

\subsection{Governing through uncertainty}

Building on earlier foundations, the 1988 military coup that established the Tatmadaw's SPDC regime was synonymous with the emergence of a totalitarian dual-state (Fraenkel 
[1941]) in Myanmar. ${ }^{2}$ Alongside the normal ministerial and local authority structures of government, the Tatmadaw has created a parallel prerogative structure that, besides an override system of regional military commands, is complete with its own business ventures and welfare and educational institutions (see Callahan 2007: 6-8). While many of the top ministerial and local authority officials are acting or retired military officers, observers describe a decision making process that is opaque and extremely difficult to penetrate. Standing isolated and aloof from the normal organs of government, several senior SPDC leaders make all the key policy decisions. Communication flows one way, from top to bottom, with ministers being little more than "... senior clerical staff". Based on a culture of 'follow the leader', a hierarchical, top down structure runs throughout the bureaucracy of government; this produces a marked disinclination of lower ranks to take any initiative unless sanctioned from above. This system creates little or no space for discussion between levels or across departmental boundaries. It discourages innovation or risk taking.

Recently, the SPDC has embarked upon a programme of partial civilianisation of the senior levels of government, including township authorities. Normally, it would not be unreasonable to read this as a small sign of liberalisation. However, if anything it has accentuated conformity. Because direct links to regional military commanders have been weakened, several aid agencies report that civilian replacements are even less likely to make independent decisions. In one case, it even involved refusing to forward a travel request to the local military authorities; a request it must be added that was granted after the aid worker concerned waited for five hours to speak directly to the commanding officer. As one respondent put it, given its inability to innovate or reform "...the only thing that the bureaucracy is capable of is repression". Apart from physical repression, this includes the ubiquitous ability to obstruct, refuse or extract rents.

A top down 'follow the leader' culture not only stifles administrative innovation, it also creates uncertainty. Regimes of government based upon the exercise of arbitrary personal power, unlike Weberian bureaucracies, lack foundation in codified rules and agreed standards. Any changes to an earlier understanding, for example, have to be renegotiated. At the same time, when a senior commander, minister or local Peace and Development Council (PDC) official changes, all the rules also change. Aid agencies, for example, have to once again begin from scratch the laborious and uncertain process of renegotiating earlier working arrangements. It would be wrong, however, to dismiss colonially-derived administrations as inefficient. The very uncertainty over what the exact rules are, or where the real power lies, or when it might suddenly reveal itself, is a powerful and productive artifice. Uncertainty functions to "... keep everyone on the edge". Even the isolation of the regime's senior figures - not only bureaucratically but even spatially in the new administrative capital of Nay Pyi Taw - is part of the theatre of uncertainty.

Uncertainty and fear regarding the location and limits of power function to promote timidity and self-censorship. Not only does the exercise of arbitrary personal power maintain discipline within government bureaucracy, it also permeates wider society. In October 2007, for example, a number of INGOs operating in Myanmar took the unusual step of issuing a public statement calling on the government to recognise the hardship existing in the country (INGO 2007). This statement was in response to government's violent suppression of the urban unrest the previous month. In the discussions surrounding this statement, it was clear to some respondents that, as the government had never previously expelled an INGO, "...no

\footnotetext{
${ }^{2}$ For the connection between colonialism and totalitarianism see Arendt [1951].
} 
one knew where the line was". In the past, however, uncertainty had been sufficient to enforce self-censorship among aid agencies. Despite several meetings, a number of the larger INGOs still declined to become involved in the joint statement. If uncertainty and fear are sufficient to routinely promote timidity among international agencies, then the same principle is even more effective among those people lacking a residential opt-out clause.

Despite the productive nature of arbitrary personal power, colonially-derived administrations represent weak forms of governmentality. While uncertainty can instil discipline, it is not as strong a liberal forms of comportment where the subject internalises and identifies with the project; where life is governed, as it were, through the powers of freedom (Rose 2000). Outside the officer corps, senior ministers, head township officials and their business cronies (together with their families and hangers on), self-identification with the regime quickly tails off. While this is obvious in the ethnic States, the same is true in the central Divisions. This design weakness means that uncertainty and fear have to be constantly backed up by a portfolio of performative technologies and artifice. Apart from the educative use of violence, central here is the permanent need for a political enemy. Several respondents, for example, discussed the regimes response to internationally imposed sanctions in this light. They lament a situation in which Western politicians appear blind to the fact that, rather than necessarily harming or threatening the regime, this war footing is, to the contrary, a political gift. Because the military "...can only solve things with guns", they prefer problems to present themselves as political opposition; that is, something that can be literally or figuratively shot at. Outcries over social hardship and legitimate dissent are thus routinely translated into terminal threats against the nation itself. All difficulties, oversights and miscalculations - even of the regime itself - become the acts of hired provocateurs, external malcontents and their devious foreign backers. The SPDC response to the September 2007 monk-led marches against social hardship was to interpret them in this manner and to initiate a familiar 'hunt the ringleader' response to what was, essentially, a leaderless protest.

Reflecting its colonial genealogy, the need to govern through emergency due to the existence of a permanent enemy interleaves with a racially inflected design of power; in this case, the tendency of the Tatmadaw regime to experience its opponents as culturally, if not biologically, inferior. The question of 'Burmanisation', or the promotion of Bamar cultural supremacy, is important here. While the various ceasefire arrangements have qualified this process, it remains an important undercurrent of the centre/periphery conflict dynamic. While respondents suggest that Burmanisation is not centrally directed, as a process it is more or less obvious and, according to location, varies in degrees of intensity. The lack of any check on the arbitrary personal power of regional military commanders, for example, produces cases of excess, including the dismissal of Church leaders and, in some places, decreed local conversions to Buddhism. Being regarded by officials as culturally backward, the Chin have been particularly susceptible to such actions. More generally, the building of pagodas in non-Buddhist areas of the ethnic States, for example, has reinforced the sense of distrust that has long stalked Myanmar's divided ethnic landscape.

Another weakness is the reliance of the regime on what could be called the theatre of success. Formed in 1993, for example, the Union Solidarity and Development Association (USDA) is held to have nearly 24 million members or 42\% of the population (USDA 2007: 13). While mainly located in the central Divisions, the USDA also has branches and village organisation in the ethnic States. While membership is officially voluntary, in practice if you want anything done or simply wish to remain on the right side of the line, it is obligatory. At the same time, many people have been enrolled without their knowledge (Callahan 2007). 
Through the USDA, together with compulsory household and village attendance levies, the regime regularly stages mass events in support of government policy or achievements. In appearance, however, these rallies are similar in that they lack spontaneity, with people marching, standing or sitting in carefully choreographed rows and files. From their wooden demeanour it is possible to detect, as one unwilling participant suggested, “...they have no support in their hearts".

A corollary of instructions flowing from top to bottom is that only good news flows in the opposite direction. In attempting to build a modern landscape of roads, bridge, universities, hospitals, power stations, high rises and dams, the regime has operated what one observer has called a "through put" model. Instead of relying on a system of taxation for such work, the SPDC and Tatmadaw have regularly given land, mining and logging concessions in exchange for investors building such a landscape. Lacking the human resources to make this infrastructure work, however, modernity remains largely imaginary. Newly built clinics, for example, are just buildings, normally empty of drugs, patients, nurses and doctors. If a senior official visits, however, the subordinate bureaucracy works to ensure that just for one day, at least, the clinic is a theatre of patients and doctors. According to one respondent, the delays in granting aid workers travel permits, especially senior figures, seems to be connected with this culture of performance. The wait allows visits to be choreographed, with "...the right official walking out of the right building just at the right time".

Although arbitrary personal power constitutes a weak design of governmentality, this should not blind us to the reality of its power effects; especially its ability to expose entire populations to the choice between acceptance and adaptation or irrelevance to the point of death.

\section{CHRONIC EMERGENCY}

Given the friendly people, comfortable hotels and relative absence of beggars, a foreign visitor to Yangon could easily believe that there is no humanitarian emergency within Myanmar. On paper, at least, besides oil and gas wealth, Myanmar is a country that should be able to feed itself, producing more rice than it consumes. Rakhine State, parts of which receive international food aid, reflects this apparent contradiction. The food-insecure communities, for example, live in zones of extensive paddy cultivation. Long before Amarta Sen (1981) developed his entitlement theory, Furnivall (1948) had recognised that in Burma progress is, if anything, negatively associated with social welfare. In so far as progress is synonymous with, for example, cash crop production, the privatisation of land ownership, the bankrupting of old industries with cheap imports or rendering traditional skills redundant, since the nineteenth century it has subject self-reliant populations to a permanent crisis of adaptation; an unending choice between change or irrelevance and death. At the same time, progress in the underdeveloped world has conspicuously failed to develop the compensatory welfare and benefit systems taken for granted in the developed. The humanitarian emergency in Myanmar is structural in character; it is a chronic emergency. It is inseparable from both the exercise of arbitrary personal power and the absence of a compensatory social welfare regime. As a global condition affecting other non-insured populations, the main international response to chronic emergency has been humanitarian intervention. Since the early 1970s, this has functioned as an international insurance of last resort for communities and peoples facing the permanent crisis of self-reliance.

\subsection{The political economy of information}


Humanitarian emergencies are popularly associated with natural disasters, wars and famine. These events visibly displace populations, destroy livelihoods and render people dependent upon external help. While the causes of humanitarian disasters are often treated separately, it is suggested here that, in the last analysis, they are the epiphenomena of the widespread crisis of self-reliance. At the centre of this permanent emergency is that ethnically animated social ecology of survival and resistance usually known as the community. Self-reliant communities have endured the challenge of endless adaptation since the colonial period. As productive entities embodying labour and laying claim to resources, self-reproducing communities and populations have long been subject to the disciplinary exercise of arbitrary personal power as a condition of their governance. A changing cast of masters and elites have regularly looked to their subject peoples as a source of tax, commodities and supplies, and once dispossessed of their land, of wage-labour too. War among the people is fought at this biopolitical level of life and livelihoods. For rival elites, the social ecology of communities and subsistence economies become points of attack and defence. Seeking to destroy a way of life, however, simultaneously strengthens the will to live. It deepens and reconfirms the ethnic divisions of plural society. This time around, however, this plural society cannot be reintegrated by nationalism. Whatever the eventual juridico-political outcome, it will have to recognise the reality of these differences.

Conflict at the level of life and livelihoods renders differences between war and peace as relative rather than absolute conditions. In times of war, martial law is liable to adopt an exterminatory stance in relation to the communities and survival strategies encountered. During peace, however, power often shifts to more extractive technologies. Populations become valuable in terms of what they can provide or be separated from. In terms of levels of dispossession, as in the case of oil concessions in southern Sudan, peace may prove to be even more disastrous than war. Over the past century and a half, Burma and now Myanmar has undergone whole cycles of annexation, destruction and ethnic adaptation. While changing their form, since independence these processes have continued unabated (Smith 2007). Following the ceasefires of the 1990s, Myanmar's plural society has been characterised by a variety of uneasy balances of force between the SPDC and its militarised ethnic opponents (Callahan 2007). Supported through the shadow economy of logging and drug cultivation, peace has seen the expansion of new forms of dispossession and displacement. In response, the social ecology of self-reliance has produced new forms of defensive circulation and migration (South 2007a). All of these shifts and adaptations are indices of the chronic emergency in Myanmar; an emergency that is both obvious and yet strangely illusive.

The problem of assessing or measuring this emergency is immediately confronted with a fundamental problem: the absence of reliable, systematic and comparable information on the state of social welfare. Moreover, this is not just a methodological problem, it is also political. Neither is this absence particularly new. In his Colonial Policy and Practice (1948), in attempting to assess the impact of colonial rule on social welfare in Burma, Furnivall was faced with the same problem. Through his own direct experience (in the Land Records Department) he was well aware that colonialism had resulted in a major decline in social welfare. From the beginning of the twentieth century into the 1930 s, he had witnessed the impact of the economic logic of "...the survival of the cheapest" upon the fabric of community life: the substitution of imports for home produce; the disappearance of village handicrafts and artisans; worsening diet; and the evisceration of cultural life. However, despite the predilection of the colonial bureaucracy for collecting information and compiling 
statistics little, if any, related directly to social welfare. The vast amount of statistics on imports, exports, tax revenues, crop yields, population figures, land holdings, livestock, and so on, were mainly collected "...for administrative purposes" (Ibid: 414). Colonial bureaucracies complied information and statistics for administrative and security reasons; they had little concern for documenting the social welfare of populations deemed self-reliant. Consequently, throughout Colonial Policy and Practice, Furnivall has to infer from the available information, including crime statistics, evidence to support what he knew from experience: the decline in social welfare.

In this respect, the contrast between colonial bureaucracy in Burma and Weberian bureaucracy in relation to the European welfare state is striking. Population as an aggregate phenomenon was discovered during the eighteenth century through the nascent science of statistics and demography. During the nineteenth century, based on a greater understanding of demographic trends and advances, for example, in the new field of public health, regulating the collective life of population was accepted as the legitimate business of state administration. Rather than social welfare being ignored, by the twentieth century it had, together with its associated technologies of surveillance, intervention and support, come to signify the reason for politics itself. Colonially-derived bureaucracies, however, continue to govern as if confronting autonomous self-reproducing populations, rather than, as in the developed world, populations whose welfare is dependent upon their statistical integration within the sinews of the state. Consequently, while post-nationalist states do collect information, this continues to be mainly for administrative and security purposes. The SPDC regime in Myanmar, with the difference that its economic data is widely regarded as flawed, is typical in continuing to reflect the informatics of the preceding colonial bureaucracy. Regarding security, while no detailed national census has been attempted since the colonial period, population at a local level is regularly counted. Villages, for example, typically have name boards that include the population size and households numbers. In the immediate aftermath of the September 2007 protests, such police knowledge was used during the night curfew in Yangon to check household occupancy in target wards.

The main difference or addition regarding colonial bureaucracy is the contemporary existence of aid agencies whose raison d'être is the measurement and commodification of human need. This has transformed a colonial disregard into a post-nationalist attitude of suspicion and restriction. As in other areas, including Africa, aid agencies, lobby groups and area experts have begun to fill the gap in the political economy of information. Especially in the context of humanitarian intervention, from the 1980s, you increasingly find health surveys, assessments of nutritional status, and attempts to understand livelihood strategies and coping mechanisms. Ignored by colonially-derived states, in many respects it is UN agencies and NGOs that have taken on the responsibility anticipated by Furnivall of the need to collect reliable information "... regarding debt, civil litigation, crime, health, education and other matters that find no place in individual budgets of income and expenditure" (1948: 417). In Myanmar, as elsewhere, such activity by aid agencies is met with a mixture of suspicion, hostility and censorship.

The government tries to restrict aid agencies to monitoring the impacts of their own programmes; anything else is done surreptitiously. The hostility of the SPDC regime to demographic surveillance stems from several considerations. Such information threatens to contradict its claim to be the infallible guardian of the peoples' welfare and development. It exposes the regime's inability to solve social and economic problems together with the absence of a viable public welfare infrastructure and its associated human resources. 
Consequently, such regimes have to turn social problems into the acts of political enemies; a military regime can only solve problems militarily. There have been a number of attempts by donor governments and the UN to engage the technical divisions of government on the need for base-line health and welfare data. One of the few limited successes relates to HIV/AIDS. For several years, the Ministry of Health has cooperated in screening for HIV/AIDS, malaria and TB. While this cooperation is far from comprehensive or problem free, it is tempting to suggest that government involvement owes more to security fears over health crises rather than a commitment to universal public welfare. Another exception, concerns the recent national household survey completed with UN support (IDEA/IHLCA 2006). A number of aid agencies doubt the accuracy of this survey; the sampling sites in border areas, for example, were not representative. At the same time, when the 'nation' is a collection of divided peoples living under different socio-ecological conditions, a number of wider objections begin to emerge. This, however, remains academic since the government has never made the results of the household survey public.

\subsection{The contours of a chronic emergency}

Given the absence of reliable or comprehensive information, there is an interest in establishing an information unit within office of the UN Resident Coordinator. The idea would be for this unit to collect together the disparate UN and INGO survey material in the interests of gaining a more comprehensive picture. While such initiatives should be encouraged, there is a politico-methodological consideration. Aid agencies are usually involved in the survey of need in order to commoditise poverty and support funding bids. In Myanmar, as in other places, this makes them often reluctant to share information. This is often justified on the grounds that sharing information is restricted under their operating agreements with the government. At the same time, reflecting the competition for resources, formal agency documents usually reflect a culture of success approach to reporting. This reportage, even when it can be collected and compared, is often of limited use in trying to capture the changing social ecology of survival and resistance of communities and peoples; in particular, how power and unaccountable force acts on people, exposing them to risk and reducing social welfare. In an attempt to get a feel for this process of change, exposure and risk, a few points of entry are now considered.

\subsubsection{The September 2007 unrest}

The monk-led urban protests in September 2007 can be read as a potent sign of the increasing poverty within central Myanmar. The immediate reason for protests was the massive ten-fold increase in the price of petrol the month before. For some observers, an increase was legitimate and had been overdue. Due to generous government subsidies, for years the price of petrol has been unrealistically low. However, rather than attempting to phase-in such a large increase, the government introduced it in one move. The manner in which this was done, and the apparent ignorance or indifference to its possible social effects, well reflects the nature of power discussed above. It also shows how the exercise of militarised sovereignty constantly exposes populations to danger and risk. By increasing the price of transport, the knock on effect of the fuel hike was to increase the price of foodstuffs and hence urban and rural food insecurity. Given that the 1988 uprising was led by students, the involvement of monks in the 2007 unrest is socially significant. The monkhood in Myanmar plays an important welfare role and can be seen as a barometer of social conditions. Similar to the army, by taking in male children, it has long functioned as a way of reducing the welfare burden of families. In the case of the monkhood, boys are fed and provided with some 
education. Due to declining social welfare, for some time prior to the petrol hike, increasing numbers of children had been arriving at monasteries seeking admittance. At the same time, monks are themselves dependent upon the charity of the people. Since less and less has been given, the welfare role of the monasteries has been constrained. The result, unprecedented since the colonial period, is that increasing numbers of boys have been turned away. The August 2007 petrol hike, with its almost immediate negative effect on social welfare, brought these mounting pressures to a head.

The young monks that were involved in the largely spontaneous protests came from all over Myanmar's central Divisions. Many would have witnessed rural poverty at first hand, some even being involved in local CBOs. Being cut off from its peoples, the Tatmadaw literally "...shot the messenger". For observers, the trajectory of the protests was clear. They began with the monk's message of poverty and social hardship. Only as the marches continued did former student leaders and the NLD add a political message. Helped by external lobby groups and the international media, this suited the SPDC regime, allowing it to deflect the charge of gross incompetence and indifference onto more familiar and less dangerous ground: external political agitators and their local 'axe handles' (NLM 2007). This repositioning also served another purpose regarding the ethnic States. The origins of the unrest can be traced to the chronic emergency in central Myanmar and the generalised employment, food and health insecurity that grips its people. This social malaise is constantly exacerbated by the exercise of arbitrary personal power. At the same time, many aspects of this malaise are shared with the ethnic States. However, the government's presentation of the unrest as resulting from foreign-backed pro-democracy agitation reconfirmed the distrust among ethnic elites regarding what many see as an 'internal' Burman political struggle. Rather than exploiting the communality between social situations, the ethnic elite response was to disparage the outpouring of international concern over the monks when, in the past, they had lost thousands of their peoples without a similar outcry. Thus, while seemingly heavy-handed and out of touch, the regime's response has reconfirmed the divisions of the post-nationalist plural society; divisions for which it claims to have the only answer.

\subsubsection{Ethnic coexistence}

In seeking to reflect on the similarities and overlaps of the social malaise in the central Divisions and ethnic States, the situation in Kachin is briefly explored. As in other ceasefire areas, one effect of the peace has been the visible widening of the gap between rich and poor. This has mainly resulted from the new opportunities afforded to unchecked personal power to dispossess or exploit landed communities, both threatening social welfare and demanding new forms of adaptation. Prior to the 1994 ceasefire agreement with the most powerful Kachin force, the Kachin Independence Organisation (KIO), travel was significantly restricted outside the main towns. The KIO, for example, was in the hills surrounding the state capital Myitkyina and had received little international assistance. Travel restrictions also meant that outside commercial interests had been kept out of the countryside. While villagers were subject to constant movement as the war ebbed and flowed, there was little land alienation. The peace is widely seen has having several negative effects relating to social welfare. The KIO, for example, assumed that there would be a peace dividend; this never materialised. The ceasefire agreement, never made public, included the prospect of development as a way of fostering trust. Both parties interpreted development as modernisation, that is, the construction of roads, schools, hospitals and mechanised agricultural schemes. Among other things, however, little effective humanitarian assistance 
was forthcoming, either from the government - which treats the regions, like the military commands, as essentially self-provisioning - or the international community.

The ceasefire groups have suffered as a result of the sanctions climate, being classified with the government and thus ineligible for direct assistance. This is argued to have problematised the transition from a military to a public administration. While the KIO has always intended to provide welfare support in the areas it administers (it has education, health and agricultural departments), it has never been fully able to assume this role. As in other ceasefire areas, there has also been a process of splitting away from the original nationality movement. Besides the KIO, the New Democratic Army - Kachin (NDA-K) and Kachin Defence Army (KDA) also have their own geographic zones of control. The NDA-K, for example, used to be communist but now declares itself democratic. For some observers, however, it is better described as a warlord entity. Being an area of uneasy coexistence between different forces (Callahan 2007), the Kachin State is divided into a number of spheres of influence and subnationality groups. Roughly speaking, besides controlling the Kachin State capital, Myitkyina, the government has most of the western regions while the area towards the State's eastern borders is split between the ceasefire groups, with the KIO and KDA also controlling small pockets of territory in the northern Shan State where other armed ethnic forces are also active.

The fact that there is no central tax or budgetary support for the Kachin State, plus the absence of international aid, has a number of serious implications for social welfare. Again, the absence of central support is common in the other ethnic States. The peace has given rise to an uneasy coexistence of forces, and each of these forces has, to varying degrees, parasitically realigned themselves to the only source of wealth there is: the land and its peoples. The regional military commanders, central government, local authorities and ceasefire groups are all engaged in extractive industries. Both sides - the state and the ceasefire groups - exploit the peasantry; the main difference is that "... where the government uses force, the ceasefire groups are likely to claim that it is a duty". For several respondents, the situation regarding land ownership has been the main negative affect of the peace. The countryside has been opened up to outside businessmen and commercial interests at the same time as the peoples multiple masters are willing to sell or lease the land irrespective of customary claims. Traditional practice is to leave large tracts of land fallow for lengthy periods. The government, for example, classifies this as waste land and thus state property. Lacking either the knowledge or resources to formally register their land, many communities have been dispossessed. Regional commanders, for example, sell concessions for jade mining, rubber plantations or sites to dredge rivers for gold to Chinese and Burmese businessmen. They also own companies in their own right. In the past logging concessions were important. Since government restrictions, however, sugar plantations are of growing importance. Whereas logging was Chinese driven and often benefited the ceasefire groups, the growth of sugar plantations is being steered more from the centre. This is a development that is indicative of the ever-changing nature of these economies.

Where the land taken is in populated areas, concessions and plantations are often fenced with some having watchmen. This restricts the villager's ability to collect firewood and building materials. With rubber plantations, it is common for owners to import their own labour, using villagers just for clearing purposes. Even to the casual observer the evidence of such practices can be seen in the despoiled countryside. There is extensive fencing of government and private plantations. Company signs, often existing poignantly besides the occasional aid agency clinic or village standpipe, brashly proclaim ownership of the neighbouring land. 
Along the rivers, one encounters fenced gold-mining compounds complete with diggers and dormitories for migrant workers. Land confiscation, however, is not the only form of dispossession to which the peasantry is subject. In place of a formal or redistributive tax system, all parties have developed informal tax regimes. Some aspects of this system can be illustrated in relation to road building. Moreover, while road construction is usually seen within development policy as essential for market integration and hence improving social welfare, in Myanmar it has often had the opposite effect.

As mentioned already, regional military commands are expected to be self-provisioning. For feeding the troops, construction and transport, commanders are largely on their own. Since the ceasefire, the military has been a big player in the construction of roads. It has done this within the limits of the resources that can be raised locally. In this respect, forced labour is common throughout Myanmar. Tasked with building a road, the military will often call upon the township authorities for assistance in their areas. This request is translated, for example, into forced village labour levies which the authorities rationalise as being in lieu of a formal tax system. In this way 150 people can be taken out of a village for a week at a time to work on the road. No pay or support is given and their families have to make do in their absence. Once completed, besides opening up the countryside for commercial exploitation, the road also becomes a system of taxation in its own right. What used to be known as 'town eating' in pre-colonial Burma is now called 'road eating' in Myanmar. A sovereign power grants an agent the authority to tax local communities in exchange for a share in the revenue. The newly built roads have regular checkpoints where, besides the military, different local government departments all have representatives, each taking a share of the transport tax. There is also a system in place to ensure that this tax actually goes to the commanders and departments concerned. In 2003, for example, there were fourteen checkpoints on the Myitkyina to China road, the cumulative levy of which was the equivalent of $\$ 150$ per trader. While commercial interests are able to absorb these costs, or through corruption negotiate an acceptable level, ordinary farmers are effectively priced off the road.

While conditions and severity vary, in all the ethnic states the peoples' multiple masters are variously involved in tributary processes of dispossession, forced labour and taxation similar to those outlined above. The ability to exercise arbitrary personal power is constantly exposing and re-exposing communities to the risks and contingencies of their existence. Such a design of power, often exercised in the name of progress, has a negative effect on social welfare by undermining the basis of self-reliance. Indeed, these modalities are part of a much wider permanent crisis of self-reliance, not only in Myanmar but across much of the 'developing' world as well. In Kachin, dispossession and a growing demand for cash, even for basic education and health care, means that labour migration figures as part of the constant process of adaptation. Kachin's post-war logging, jade and gold mining areas, for example, are important nodal points on circuits of migration that now connect lower Myanmar with China. Household members are away for varying portions of the year. Such migration is tough. In mining areas workers are often promised a third of the profit. They rarely get this however since they are never sure what, exactly, the profit is. Moreover, if they complain, they are dismissed. As a measure of the alienation that exists, drugs are prevalent in the town and rural areas. This includes heroin and amphetamines. Drugs, together with sex workers, are also attracted to the mining and logging areas. These circulatory nodal points are important vectors for Myanmar's HIV/AIDS epidemic.

These pressures are all part of the malaise and sense of post-ceasefire demoralisation that exists in Kachin as in other ceasefire areas. There is a feeling that foreigners, especially the 
Chinese, for example, are slowly consuming the natural wealth of Kachin. Lacking any assistance, the KIO is blamed for the absence of material progress. This has fed into competition and animosity between generations. Ex-soldiers, for example, find themselves with new responsibilities and families to support. However, there has been no attempt to rehabilitate or reintegrate such people. During the war "...they were someone, now the families have to deal with this". Alcoholism and drug use is common. The youth feel frustrated and have little hope for the future. The standard of higher education available regionally is low, offering little training and few job prospects. Opportunity permitting, there is a great yearning to leave Myanmar altogether. One respondent summed up the present malaise as "...no war...no life".

\subsubsection{The absence of public welfare}

While the nature of the chronic emergency in the central Divisions and the ethnic States has different modalities it interconnects in many ways. Apart from such things as labour migration, at the root of the shared crisis of self-reliance is the exercise of arbitrary personal power. This constant exposure to death is also compounded by the failure of the same masters to develop a compensating system of public welfare.

The majority of the population does not have access to anything that could be described as even adequate health care. While the government builds hospitals, for example, it has not provided the human resources in both quality and quantity to staff them. What central provision does exist is usually confined to the towns, missing much of the rural areas where the majority of the population lives, as well as excluding many ceasefire zones. Moreover, even this has been undermined by de facto privatisation. Until recently, for example, state doctors were paid only $\$ 30$ per month, encouraging endemic moonlighting. While nominally attached to a public hospital or clinic, most consultations and treatment are provided in an unregulated private sector that ranges from "...a hole in the wall to a clinic with nurses and doctors". Again, however, this is largely confined to urban areas. When average earnings are 3,000 kyat per day, "...even just to touch" can cost 5,000 kyat. The treatment of HIV/AIDS is illustrative of the absence of an adequate welfare system. Although the 3D Fund has sought to augment government service, its penetration of the countryside is reliant upon the availability of suitable NGO and UN implementing partners rather than reflecting the incidence of need. Even this provision however is hampered by lack of international funding. At present, there is a restriction on further testing and treatment. The result is that an estimated 60,000 people (based on the testing that has been done) are not receiving the anti-retroviral treatment they need (UNCT 2007). A similar picture exists in relation to malaria and TB. Outreach through aid agencies is fragmented, dependent upon partner availably and, due to resource limits, treatment levels are capped. Rather than current interventions giving a generalisable picture of morbidity in Myanmar, it is more the case that wherever partners can be found and local surveys undertaken, morbidity is encountered. The problem is that there is nothing joining the dots.

A similar picture exists in relation to education. Even at the level of primary education, a similar process of de facto privatisation is encountered. While the government builds schools, it is common to find them with insufficient or no teachers, particularly in rural areas. Consequently, poor communities to have to bear the cost of providing school books, accommodation and teacher salaries. As a result of such pressures, it is estimated that more that half of Myanmar's children do not finish primary school (UNCT 2007). This malaise runs throughout the educational system, including higher education. The universities in 
Yangon, for example, while the best that the country can offer, are widely regarded as no longer providing the standard of training necessary to produce competent professionals. While English is the official language in much of higher education, since the 1960s there has been a long term decline in the prevalence and quality of its teaching with the result that, although exam questions in some subjects are set in English, both the teaching and answers are given in Burmese. At the same time, claims of corruption, plagiarism and cheating are commonplace. Many respondents feel that a clear educational generation gap now exists. One LNGO reported that if recruiting an accountant, for example, they would, of necessity, disregard anyone who has graduated since 1990. This malaise is connected with another widely perceived development: the collapse of Myanmar's professional middle-class. Greatly weakened by political flight and emigration, it is no longer being replenished through Myanmar's educational system. This bodes ill, not only in terms building an adequate welfare system, but in relation to the negotiation and brokerage that any political transition would require.

The gap between the exercise of arbitrary power and the exposure of populations to risk on the one hand, and the absence of adequate public welfare on the other, mark out Myanmar's chronic emergency.

\section{THE OPERATING ENVIRONMENT}

From the preceding discussion, it can be argued that the broad aim of a humanitarian action in Myanmar is to help push back, contain or modulate the effects of unchecked, arbitrary personal power. Even where this has been done, however, an important challenge remains: the absence of a compensatory system of public welfare. In achieving this aim and, especially, facing this challenge, many aspects of the current aid architecture within Myanmar are ill-suited to the task. Section 2.4, for example, has outlined the incomplete and divided UN and donor presence resulting from the international climate of sanctions and restriction. The main intention here is to examine how, despite a difficult working environment, international aid agencies, LNGOs and CBOs have succeeded in opening a humanitarian space, albeit fragile and contingent, that offers some degree of protection for local communities. In order to examine this space, humanitarian action is first placed in a wider historical context.

As already argued, the endemic humanitarian emergencies beyond the borders of mass consumer society are indicative of a permanent crisis of self-reliance. While widely assumed to be a normal attribute of underdevelopment, for a large part of humanity self-reliance has been increasingly problematic since the formation of an integrated world economy at the end of the nineteenth century (Davis 2001). With the opening of the Suez Canal, the advent of the steam ship and electric telegraph, and the spread of the railways, the great peasantries of Africa and Asia were brought into direct competition with the farmers of the vast American prairie and Russian steppe. Furnivall (1948) was acutely aware of the negative effects of this competition on social welfare in colonial Burma. He dubbed it the survival of the cheapest. In the heroic days of independence, for a short time nationalism and socialism attempted to give some protection; in general however, the crisis of self-reliance has deepened since decolonisation. Although humanitarian intervention has a long history, as an international system it is relatively recent. In terms of specialist UN relief agencies, dedicated donor emergency units and, importantly, the thickening interconnections between them and INGO practioners in ways that are recognisable today, the international humanitarian system can be dated to the post-Biafra war era of the early 1970s (Kent 1987). 
One can understand the emergence of an international humanitarian system in two ways. From a humanist perspective, it reflects the growing enlightenment and civilisation of a Western-led international community. This is the common interpretation. An alternative explanation, however, exists. By the early 1970s, the crisis of self-reliance amongst the world's non-insured populations - a crisis that had been deepening since the end of the nineteenth century - had reached a global tipping-point. Prior to the 1970s, the crisis of selfreliance had been contained within individual countries; since then it has become international and, initially framed terms of increased refugee flows, global in its ramifications. In relation to this tipping point, the international humanitarian system both separates and interconnects the developed world, where life is supported through insurancebased systems of social protection, and the underdeveloped world, where life is expected to be self-reliant. In relation to the latter, the humanitarian system functions as a form of international insurance of last resort. This system is fraught with imperfections, serious limitations and comes complete with its own small-print. In countries like Myanmar, however, where people are routinely exposed to risk through the exercise of unchecked personal power, humanitarian intervention is often the only thing that stands between them and irrelevance to the point of death.

In response to both the government's and the external lobby groups attempts to restrict international aid in Myanmar, the $\mathrm{UN} \mathrm{RC} / \mathrm{HC}$ has used the humanitarian principles of neutrality, impartiality and transparency as a buffer between these opposing forces in the interests of addressing the chronic emergency among the people (Petrie 2005; Petrie 2007a). This is a wider application of these principles than is normal. The intention it to move beyond basic humanitarian assistance per se, to include other aspects of social welfare, such as education, employment and health, the degradation of which deepens the malaise. This endeavour deserves further attention and elaboration. It suggests the reinterpretation of the crisis of self-reliance in terms of a complex and multilevelled social ecology of survival and resistance. While immediate life-supporting interventions remain a vital insurance of last resort, unless the ambit of humanitarian protection is widened to include the other interconnected modalities of this social ecology, the whole humanitarian project is constantly undermined and threatened with failure. What is interesting about Myanmar is that LNGOs and CBOs, in attempting to expand in a restrictive environment, have already pioneered in a practical sense how humanitarian action and principles can be made to operate in such a difficult setting.

The preceding analysis of the nature or power hinges upon the performative function of violence and the utility of arbitrary personal rule in maintaining a climate of uncertainty and fear. At the same time, however, this mode of governance suffers from a number of weaknesses; for example, the limited ability of the regime to induce people to internalise their loyalty and become self-governing: hence, the constant theatre and performity of government. Apart from the apparatus of security, there is a gap between the generality of uncertainty and the ability of the state to be certain of outcomes. It has to contend with the constant possibility that directives are not followed. In choosing to receive only good news, there are plenty of other things besides the bad that are never heard. It is this gap between fear and the inability to guarantee local outcomes that creates a practical 'space' for humanitarian action in colonially-derived states.

\subsection{Below the radar}


While the UN system has a longer pedigree, an NGO presence inside Myanmar, both international and national, began to emerge in the early 1990s, partially in response to the ceasefire agreements. By the end of the decade, most of today's main organisations were already established. Together with their representative's name, office address and contact numbers, about fifty INGOs and eighty LNGOs are listed in Yangon agency directories. In terms of having a significant programme or field presence, however, the number of effective NGOs is less than this. CBO numbers have been estimated from a low of 1,500 to 10,000 or more. It is not uncommon to find 2 or 3 such organisations in a single village. Again, however, many of these organisations exist in name only. A few INGOs had previously operated from Thailand on the borders and decided to move inside following the ceasefires. A few LNGOs were also encouraged by the same events. Others emerged in response to the INGO search for local partners. Many CBOs have similarly come into existence as a result of both INGO and especially LNGO activity. Despite uncertainty over exact numbers, there is a vibrant and active NGO sector in Myanmar which, largely dictated by resource and partner availability, is operating over most of the country. Indeed, the only areas that are politically restricted are parts of the border areas in Karen (Kayin) and Karenni (Kayah) States. Even here, however, one INGO has recently gained access.

In general, the operating condition for NGOs within Myanmar is similar to other difficult environments. The attempts to register and control NGOs are reminiscent, for example, of Sudan. In Myanmar, all INGOs need an agreed Memorandum of Understanding (MoU) with a relevant ministry in order to operate (LNGOs require a 'registration'). A decade ago, when NGOs were still relatively new in the country, MoUs tended to be rather general, not having a specific time-limit or geographical location. Some INGOs have several with different ministries. More recently, however, MoUs have become increasingly specific, more detailed and requiring periodic renegotiation. The granting procedure has also become more laborious and uncertain, in some cases taking more than a year for completion. In response to agency requests for clarification of the procedures, the government issued a set of Guidelines in 2006 for all UN agencies, INGOs and LNGOs seeking to work in Myanmar. There has been some concern among aid agencies over the Guidelines, including discrepancies between the English translation and the Myanmar original; in particular, a number of key things are missing from the former. Importantly, the full version provides a vision of extensive bureaucratic control. The Ministry of National Planning and Development (MNPD) is given a key mediating role between the NGO and the relevant ministry. Detailed requirements for submission and approval are described. The recruitment of national staff is made the prerogative of the MNPD and, besides rules for granting travel permits, the opening regional offices, project implementation, monitoring, and so on, the Guidelines call for a series of extensive co-ordinating committees from the central ministerial level through state/division committees down to the township. At each level the committees are supposed to include the appropriate arms of government including security, planning, social welfare, education, health, immigration, war veterans, women's affairs and USDA.

The reality of the Guidelines, however, is that little of this vision has been implemented; beyond uncertainty and fear, together with the military exercise of performative violence, the state lacks the human resources to govern in detail. Like its 'through put' vision of modernity, administrative competence is largely fanciful. All that militarised state sovereignty can rely upon is the uncertainty of its location, and when and where it might decide to appear. In practice, NGOs still deal direct with the relevant ministry, no coordination committees have been convened and, while attempts to monitor do take place, even this is ineffective. While the USDA, for example, would like to control NGO resources, 
they either do not have the liaison officers or, even when present, their heart is not in the job; most times "...they stay in the hotel, or after a day in the field go back to Yangon". Because of the uncertainty and lengthy time to get approval, many NGOs, especially LNGOs, either have no MoU or use the fact of just submitting a formal request as sufficient grounds to carry on working in the interim. As a corollary to lack of implementation of the Guidelines, NGOs that already have MoUs have learnt how offset their restrictive nature by stretching them. One example concerns an agency that has an agreement with the Ministry of Health but runs a number of micro-finance projects under this MoU. The rationale is the any income earned helps people pay for health care. In this way, the Ministry of Health "...provides cover for a lot of other work". Within Myanmar this type of activity is often dubbed below the radar. It challenges the view of the external lobby that nothing is possible in Burma because it is a police state. In a sense, however, the idea of 'below the radar' is misleading. What these actions actually reflect is the nature or power in Myanmar and its limitations. In this respect, it is far from the case that nothing is possible.

It has already been mentioned that, during the 1990s, some elites associated with the ceasefire groups were active in forming LNGOs and approaching INGOs for support. At the same time, INGOs themselves have promoted the formation of LNGO partners both as a normal part of capacity building and, at the same, time, as a way of countering the increased travel restrictions to which they are subject. A decade ago, for example, a number of INGOs established a joint mechanism for training their own local staff. This was subsequently expanded to LNGO staff training and, more recently, has further developed to include regular coordination meetings between INGO and LNGO representatives based in Yangon. The formation of consortia, such as this, is a further example how otherwise restrictive MoUs can be stretched. INGO members, for example, have a variety of MoUs covering different ministries and sectors. By pooling MoUs, the group as a whole has an extensive coverage. Some township authorities will allow an LNGO to work, even if it has no MoU, providing it has a link with an INGO that does. Despite the restrictive environment, this type of innovation has helped support the geographical extension of NGO activity within Myanmar. Apart from individual assistance, a division of labour around specific issues is common. In relation to HIV/AIDS, for example, such things a sourcing funds, awareness training, diagnosis and providing treatment is divided between UN agencies, INGOs and LNGOs in relation to competence and access. Regarding this expansion, finding ways around the restrictions and suspicion of government is not the only problem. In the same way as donor governments have generally declined help to ceasefire groups, there is also an antipathy towards directly funding LNGOs. In one case, funding flows from the donor through the UN and an INGO before arriving at its LNGO destination. Due to the restrictive international climate, aid laundering is also a feature of the innovative measures necessary to address Myanmar's chronic emergency.

Before the issue of protection is examined, a different form of stretching could be called negotiating up. Besides travel restrictions, the state is more sensitive to aid agencies working in some areas than others. HIV/AIDS and vaccination work, for example, is seen as easier than, for example, education. In the case of one INGO, however, although having no MoU with the Ministry of Education, it has still been able to pilot a new primary level curriculum in twenty-five schools. One clear example of negotiating up, however, concerns a couple of INGOs that were involved, some years ago, in repatriating children from Thailand and reuniting them with their parents. This was illegal since the agencies concerned did not have MoUs covering this work. However, both used to travel to the border with a middle ranking official to bring the children back into Myanmar. Progressively, however, working with the 
officials involved this relationship was 'negotiated up' the bureaucracy until now it is an official policy between the Ministries of Social Welfare on either side of the border. Another respondent described how this process works. Given the fear and uncertainty within government bureaucracy, you work up from the project level. The aid agency first convinces the lower level administrators as to the advisability of some action. Then the person next up the chain is contacted and also convinced. By working through the levels of bureaucracy in this way, and making sure that aid people with sufficient seniority are involved in the latter stages, it may be eventually possible to convince the senior official involved. Once this is done, all the lower ranks are already in place.

\section{The business of protection}

The single most important factor in relation to the expansion of aid agency activity something that came up time and again in discussion - is the protection that just the presence of UN agencies, INGOs and LNGOs affords communities otherwise subject to the exercise of unchecked personal power. Regarding work at the community level, protection works according to the proximity of an external organisation or person that has - or is thought to have - the ability to witness and report. The more international the organisation or its representatives (for example a UN agency or INGO), the stronger the protection; however, LNGO personnel, INGO national staff, or even educated town dwellers, have a similar effect. If a village-based CBO, for example, is supported by an LNGO, INGO or religious network, the fact that outsiders are able to come and ask questions, has a tempering effect.

Conversely, the more international the organisation or representatives are, the greater the travel restrictions that are imposed. Expatriate INGO workers, for example, are usually confined to the major towns, having limited possibilities of visiting rural communities. In comparison, national INGO staff are less restricted. In this respect, while international agencies are supporting LNGOs and providing a degree of protection, it is LNGOs and the national staff of INGOs that, largely independently, have innovatively opened and shaped a humanitarian space within Myanmar.

The creation of village CBOs are important for the implementation of LNGO and INGO programmes. Typically, the NGO will visit a village and select a number of people, usually from among those able to read and write, and form them into a committee. Such groups are trained in rapid appraisal techniques in order to survey local need and, in consultation with the rest of the village, to agree a plan of action. Initially, this is usually a small project through which the $\mathrm{CBO}$ can establish itself. Completion of this project can lead onto larger undertakings. One INGO interviewed, for example, is working with 28 such CBOs. Importantly, there are two levels to this work. First, there is an official level which revolves around the activity itself, for example, a micro-credit scheme, a buffalo bank or an agricultural extension project. This is the level of the report to the government, local authorities and funding bodies. It describes the project, its aims and achievements. LNGOs have learnt how to write such reports including what to say and what not to say. There is a second below the radar level, however, which while not hidden, is seldom publicly discussed. It is this level, however, that reflects how humanitarian principles are being adapted and implemented. This is the level at which the project or programme gets negotiated and accepted by the local power-brokers: the military command, township authorities and the USDA. A number of techniques are involved. One of these is to look for a sympathetic "flexible person" from among the local power brokers who can be used to exploit the personal relationship involved to gain wider support. Apart from local knowledge, however, transparency is a key condition. 
Several respondents emphasised that agency work needs to be clearly defined as apolitical in nature. It relates to the social and welfare needs of people and not a particular political interest. In order to avoid suspicion, a wide a range of elites and functionaries are notified of the work and, if possible, involved in some way. Military commanders, local government figures and USDA representatives, for example, are regularly invited to opening ceremonies or anniversaries. Rather than confronting the authorities, the attempt is to co-opt them. There is a perceived need to "...expose the middle level [of the bureaucracy] to what we are doing". Whereas foreigners can leave, LNGOs, INGO national staff and CBOs have to stay. The aim is therefore to try to see things in the long-term. To develop ways of "..saying no without saying no". Putting the safety of the villagers and CBOs first is a priority. People have to feel happy with what they are doing; hence the strong emphasis on transparency. While this approach is apolitical in terms of organised politics, it has important political effects. Not least, through transparency and the involvement of power brokers, the protection afforded communities is increased. The way NGO projects are negotiated make it more difficult to arbitrarily exploit and dispossess the community. This engagement also creates new possibilities and conversations. In this respect, a few notable successes have been scored. For example, through the process of engagement, several community forestry projects, involving a number of INGOs, LNGOs and CBOs, have recently been approved in Kachin State. These projects give a degree of land entitlement that, in the past, the communities concerned have never enjoyed. The act of engagement over social issues creates dynamics that, unavoidably, question the nature of power.

\subsection{The failure of development}

The humanitarian space that NGOs have established using the principles of neutrality, impartiality and transparency is a major achievement. Not least, because of the increased protection that this has given the communities concerned. Given the resources, this protection is capable of further expansion. If it has a limitation, it is not at the level of negotiation, local problem solving and protection. It is more to do with the official aims of the projects concerned. This limitation relates to how the relationship between humanitarian action and development is popularly understood. This is usually in terms of a relief to development continuum where short-term humanitarian assistance must, in some way, support the transition to long-term development. In the past, the humanitarian aspect of this equation that has been regarded as problematic; for example, encouraging a dependency on free handouts or inadvertently fuelling conflict (Anderson 1996). Humanitarian assistance, however, has consistently shown itself able, even in the most difficult circumstances, to save lives and protect livelihoods. Contrary to conventional wisdom, the problem in the relief to development equation is not humanitarian assistance, it is the failure of the liberal doctrine of development to deliver on its promise. Since the 1970s, humanitarian assistance has functioned as an international insurance of last resort in relation to the permanent crisis of self-reliance. After each disaster, however, liberal development invariably comes to the conclusion that the problem is not the impossibility of self-reliance under global conditions but, in fact, the opposite; that the population concerned is not self-reliant enough. As the humanitarian emergencies that have been rolling around Africa for decades suggest, this episodic attempt to re-establish self-reproduction simply sets communities up for the next emergency, when this dismal cycle starts all over again.

The effects of this limitation can be seen in Myanmar. Through local action a largely indigenous humanitarian space has been opened up at the level of community. The 
restrictions to the further expansion of this space are more to do with lack of funding and resources rather than outright political opposition. Based upon an adapted use of humanitarian principles, where it exists this space has pushed back and modulated the exercise of arbitrary personal power. In terms of furnishing this space, however, largely through the INGO link, one finds examples of the standardised micro-finance, agricultural extension and capacity building programmes that exist anywhere in the world where international NGOs operate. LNGOs, CBOs, church networks and ceasefire groups in Myanmar's ethnic States, for example, have all adopted a similar range of projects. The essential aim of this generic NGO basic needs-type portfolio is to return the communities concerned to a state of self-reliance. Even if successful, such projects can seldom deliver more than a state of equilibrium in which poverty is managed rather than reduced. Rather than material advancement, typically such work places greater emphasis on training, awareness raising and other forms of behavioural change. Given that the decline of social welfare is largely the result of dispossession, taxation and arbitrary exactions, there is also an unfortunate paternalistic and 'blame the victim' undertone in much of this approach.

\section{CONCLUSION}

This report is not an evaluation of the aid programme within Myanmar. It provides a rapid appraisal of the humanitarian situation and tries to place it in a wider context. While detail may be lost, a rapid appraisal does have some advantages. In particular, it encourages a focus on what people say, and what they judge to be the main issues and difficulties involved. It does mean, however, that recommendations are necessarily broad in scope. Indeed, rather than recommendations as such, the conclusion brings together a number of suggestions and issues to support an ongoing conversation and search for alternatives. In this respect, if this report contributes in some small way to the ongoing debate over Myanmar, it will have served its purpose.

Owing to the nature of the regime and the activities of the lobby groups, working directly with the state in Myanmar has been problematised on two accounts. Not only is the state not amenable to international cooperation but, even if this were the case, it would not be accepted by the main donor governments. This standoff, however, is useful in that it calls into question much of fragile state policy; a policy that requires at least some acceptance on the part of the state of the international aid effort. In the absence of these conditions, Myanmar creates a new challenge for humanitarian policy (Cliffe and Petrie 2007). As a contribution to this conversation, this report has argued that Myanmar's chronic emergency has two interconnected aspects:

f First, is the historic dominance of a design of power based upon emergency and the unchecked exercise of personal authority. While functional in terms of providing a means of governing through uncertainty and fear, this power constantly exposes subject communities to the risks and contingencies of life. In so doing, it forces unending adaptation and undermines social welfare.

$f$ Second, these power effects are magnified by the absence of an adequate compensating public welfare system. In large measure, this results from the assumption - again of historic standing - that Myanmar's population is largely selfreproducing in terms of its basic biological, social and economic needs. In its essentials, this assumption is shared by the regime and international aid agencies. 
In a sense, attempting to break this developmental malaise is not dependent upon aid policy as it cannot be rectified through technical means. At the same time, theoretical critique alone is of little use; it has already been done to the point of monotony for little return. Political problems can only be addressed politically. In this respect, Myanmar's anomalous, isolated and polarised situation is an advantage rather than a liability. It means that a wide variety of incomplete and dissatisfied actors can potentially be mobilised around the complex issues involved. In the spirit of supporting an ongoing dialogue, it is suggested that an alternative approach to chronic emergency has two interlinked elements. First, rather than reconstructing the institutions of a fragile state, the onus is on pushing back, containing or domesticating a colonially derived design of power. From issues of capacity-building, the concern is more that of developing political, juridical and constitutional means to contain government through emergency and the exercise of arbitrary personal power. Second, rather than self-reliance the concern is to explore the possibility of more universalistic forms of social protection. In a sense, it is a shift from human security to social security. Before the rationale for these adjustments is outlined, there is another factor relating to Myanmar's developmental malaise that is fundamental to both.

$f$ After decades of ethnic warfare, nationalism is no longer an option for bringing the country's divided peoples together. In this sense, it is a post-nationalist society. A fundamental question lying at the heart of any future conversation is what can induce dialogue or unite all parties? And, if this is not possible, how can a federal solution under modern conditions work?

\subsection{Containing power rather than reconstructing states}

In 1993 the SPDC first established a National Convention that, among other things, was set the task of agreeing a draft constitution for Myanmar. Coming in the wake of the government's refusal to recognise the 1990 elections, and the NLD's subsequent boycott of the $\mathrm{NC}$, the international community has, perhaps understandably, both ignored and dismissed this development. It is widely interpreted as a means of entrenching the Tatmadaw's position. However, a sovereign power having the ability to suspend the law and rule through personal diktat, short of revolutionary overthrow and systematic annihilation, can only be contained through the jurido-political checks and balances of an effective constitution. While the NC process is problematic, at least the possibility of separating legislative and executive powers, indeed, of establishing a legislative power at all, was broached.

In relation to Europe, the historic struggle against the sovereign power of the monarchy is instructive. While varying from country to country, by the end of eighteenth century commoners had the right to own property, free speech, assembly and travel. This was long before universal suffrage. In some European countries this was not achieved until after WWII and, in the USA, it had to await the Voting Rights Act of 1965. Aid policy all too often forgets this history. The need to constitutionally contain arbitrary power, especially in former colonies, has been neglected in favour of a push for relatively easily representational elections. Rather than working in harness with constitutional reform, in many crisis zones, the result has been an international rubber-stamping of unstable ethnic plebiscites allowing states to use the legitimacy of electoral victory to justify continued despotic rule (Zakaria 1997). 
One view from inside Myanmar is that, whatever the future holds, the military will be part of it. At the moment, the Tatmadaw outnumbers the combined military forces that the exhausted ceasefire and non-ceasefire groups could muster against it, even if such a unity of purpose existed, which it does not. A best hope would be a constitutionally contained military that has stepped back from formal politics, as in Thailand, Indonesia or Chile, for example. However, little international assistance has been given to help resolve the constitutional issue. Regarding the regimes critics and opponents, there is a lack of resources and expertise in this field. Some of the ceasefire groups that have remained within the NC process have done so within a world-view that harks back to the constitution at independence. Hampered by a lack of resources, they tend to ignore the perhaps more relevant examples from the region and beyond of contemporary attempts to contain sovereign militarism. The present situation is one of frustration with the NC process. Other than having the dogged effort to have their views recorded, the feeling is that little has been achieved.

Activists within central Myanmar have different but not unconnected views. Again, there is a feeling that the international community has missed an opportunity with the NC process. For some, the call for democracy owes more to the emotions than objective reality. It is being proffered as a solution to all Myanmar's ills when its requirements and responsibilities either do not exist or are poorly understood. At the same time, despite their external prominence, through flight, emigration, repression and all-or-nothing zealotry, the opposition political parties within Myanmar are now shells of what they were. The need to contain arbitrary personal power through political, legal and constitutional means, apart from providing a potential platform for dialogue, is one thing that might be capable of bringing Myanmar's plural society together: even if only to find a way of living in ordered separation.

\subsection{From human security to social security}

The need to improve social welfare is central to constitutional and democratic reform. Rather than self reliance, however, the issue in question is the absence of effective and structural welfare support for the majority of Myanmar's peoples. In addressing this issue there is one obvious starting point.

a) The incomplete international aid architecture

The incomplete aid architecture in Myanmar and restricted mandates of some UN agencies is the result of the politicisation of aid. Even while accepting the wish not to work through or strengthen the state, politicisation has rendered existing aid less effective than it could be. The restricted UNODC and ILO mandates, for example, are cases in point. A case exists to review the situation with a view to rationalising the aid architecture in order to increase the range and depth of social welfare support. Important here is the position of the ceasefire groups, LNGOs and CBOs and under what conditions could international assistance be provided.

b) Reform and extension of public welfare

Perhaps more importantly, there is a need to take stock of the existing situation regarding social welfare. There is a need, for example, for a review of the existing public welfare infrastructure in Myanmar. This should examine the extent and limitations of government provision, its funding, ethos, training of staff and public access. The intention would be to find out what exists in the public sphere and how, if at all, it could be reformed. Ideally, this 
would be supplemented by examining the actually existing conditions of life and survival within Myanmar. This would attempt to go beyond the fragmented aid statistics and, where possible, use ethnographic techniques to create a picture of the social ecology of existence, including both its ethnic dimensions and points of overlap. Importantly, it would seek to ascertain to what extent communities are, indeed, self-reliant and capable of meeting their own welfare needs, both in terms of family inputs and, with cash derived from farming and labour migration, through the purchase of services.

The aim of this overall enquiry would be to feed into a debate about structural, that is, nonprojectised, solutions to Myanmar's chronic emergency. While there is a place for NGO provision within a comprehensive welfare system, there is also a need to explore more comprehensive and generalisable forms of support, including pension provision. This exploration would include possibilities relating to the reform of the budgetary process and taxation system. Gathering comparative evidence from social protection systems existing in other parts of East Asia is important here. Apart from the state hostility, such a conversation would also have to confront many of the assumptions of liberal development policy. However, in terms of looking for an inducement for dialogue in post-nationalist society, welfare reform and a more aspirational view of what development should be cannot be ignored. It is in the desire for a more secure future that issues relating to constitutional reform and welfare support merge and complement each other. 


\section{References}

Agamben, Giorgio. 2005. State of Exception. Chicago and London: University of Chicago Press.

Anderson, Mary B. 1996. Do No Harm: Supporting Local Capacities for Peace Through Aid, Local Capacities for Peace Project, The Collaborative for Development Action, Inc, Cambridge, MA.

Arendt, Hannah. 1994 [1951]. The Origins of Totalitarianism. New York: Harcourt, Inc. Callahan, Mary. 2007. "Political Authority in Burma's Ethnic Minority States: Devolution, Occupation, and Coexistence." Policy Studies 31 (Southeast Asia), East-West Centre, Washington. . 2002 State Formation in the Shadow of the Raj: Violence, Warfare and Politics in Colonial Burma. Southeast Asian Studies 34, no. 4: 513-36.

Cliffe, Sarah and Petrie, Charles. 2007. Opening Space for Long-Term Development in Fragile Environments: The Critical Role of Humanitarian Aid. Draft

Cowen, M P, and R W Shenton. 1996. Doctrines of Development. London and New York: Routledge.

Davis, Mike. 2001. Late Victorian Holocausts: El Nino Famines and the Making of the Third World. London: Verso.

DFID. 2005. Why We Need to Work More Effectively in Fragile States, Department for International Development, London.

Duffield, Mark. 2007. Development, Security and Unending War: Governing the World of Peoples. Cambridge: Polity Press.

Eide, Espen Barth, Anja Therese Kaspersen, Randolph Kent, and Karen von Hippel. 2005. "Report on Integrated Missions: Practical Perspectives and Recommendations ." Independent Study for the Expanded UN ECHA Core Group.

Foucault, Michel. 2003. Society Must be Defended: Lectures at the College de France, 1975 76. London: Alan Lane, The Penguin Press.

Fraenkel, Ernst. 2006 [1941]. The Dual State: A Contribution to the Theory of Dictatorship . London: Lawbook Exchange Ltd.

Furnivall, J S. 1948. Colonial Policy and Practice: A Comparative Study of Burma and Netherlands India. Cambridge: Cambridge University Press.

Harrison, Graham. 2004. The World Bank and Africa: The Construction of Governance States. London: Routledge.

Hussain, Nasser. 1999. Towards a Jurisprudence of Emergency: Colonialism and the Rule of Law. Law and Critique, no. 10: 93-115.

ICG. 2006. "Myanmar: New Threats to Humanitarian Aid." Asia Briefing No. 58, International Crisis Group, Yangon/Brussels.

IDC. 2007. "DFID Assistance to Burmese Internally Displaced People and Refugees on the Thai-Burma Border." Minutes of Evidence , International Development Committee, House of Commons, London.

IDEA/IHLCA. 2006. Integrated Household Living Conditions Survey in Myanmar: Vulnerability-Relevant Information, IDEA International Institute, Quebec City, Canada \& IHLCA Project Technical Unit, Yangon, Union of Myanmar. With support from: Planning Department and Central Statistical Organisation of the Ministry of National Planning and Economic Development, Yangon, Union of Myanmar \& UNDP, Yangon, Union of Myanmar, Yangon, Myanmar.

INGO. 2007. "Joint Statement." International Non-Governmental Organisations, Yangon.

Kent, R C. 1987. Anatomy of Disaster Relief: The International Network in Action. London: Pinter Publishers. 
Leader, Nicholas, and Peter Colenso. 2005. "Aid Instruments in Fragile States." PRDE Working Paper 5, Poverty Reduction in Difficult Environments Team, Department for International Development (DFID), London.

Ni Ni Myint. 1983. Burma's Struggle Against British Imperialism: 1885-1895. Rangoon: The Universities Press.

NLM. 8 October 2007. Its Time to Take the Correct Path. The New Light of Myanmar, p. 6.

Petrie, Charles. 2005. Briefing Note to the Administrator, Office of UN Resident Coordinator, Yangon.

- 2007a. Humanitarian Situation: June 2007, Office of the UN Resident and Humanitarian Coordinator, Yangon.

Rose, Nikolas. 2000. Powers of Freedom: Reframing Political Thought. Cambridge: Cambridge University Press.

Select Committee. 2007. "The Impact of Economic Sanctions: Response of the Secretary of Sate for Foreign and Commonwealth Affairs." Second Report of the House of Lords Select Committee on Economic Affairs: Session 2006-07, London.

Shenhav, Yehouda, and Yael Berda. 2007. The Political-Theological and Racial Foundations of Colonial State Bureaucracy: Juxtaposing the Israeli Occupation of Palestinian Territories with Colonial History. Paper presented at International Workshop on Power, Rule and Governmentality in Zones of Emergency: The Israeli Occupation in a Global Perspective. Jerusalem: The Van Leer Jerusalem Institute .

Smith, Martin. 2007. "State of Strife: The Dynamics of Ethnic Conflict in Burma." Policy Studies 36 (Southeast Asia), East-West Centre Washington, Washington.

South, Ashley. 2007a. "Burma: The Changing Nature of Displacement Crises." RSC Working Paper No.39, Refugee Studies Centre, University of Oxford.

South, Ashley. 2007b. Karen Nationalist Communities: The 'Problem' of Diversity. Contemporary Southeast Asia 29, no. 1: 55-76.

Taylor, R H. 1995. Disaster or Release? J S Furnivall and the Bankruptcy of Burma. Modern Asian Studies 29, no. 1: 45-63.

TBBC. 2004. Internal Displacement and Vulnerability in Eastern Burma, Thailand Burma Border Consortium, Bangkok, Thailand.

Torres, Magüi Moreno, and Michael Anderson. 2004. "Fragile States: Defining Difficult Environments for Poverty Reduction." PRDE Working Paper 1, Department for International Development, Poverty Reduction in Difficult Environments (PRDE) Team, London.

UNCT. 2007. Statement of the United Nations Country Team in Myanmar on the Occasion of UN Day, Office of the UN Resident and Humanitarian Coordinator, Yangon.

USDA. 2007. Facts Relating to the Union Solidarity and Development Association, Government of the Union of Myanmar, Yangon.

van Creveld, Martin. 1991. The Transformation of War. New York: Free Press.

Van Hoyweghen, Saskia. 2004. "Migration and the Nation-State: The Case of Displaced Rwandans in Tanzania." PhD Dissertation, University of Leeds, School of Politics and International Studies.

Wood, Geof, and Ian Gough. 2006. A Comparative Welfare Regime Approach to Global Social Policy. World Development 34, no. 10: 1696-712.

Zakaria, Fareed. 1997. Democratic Tyranny. Prospect, no. 25: 20-25. 


\section{SPAIS}

Working Paper Series

WP 01-08 Mark Duffield, 'On the Edge of "No Man's Land": Chronic Emergencies in Myanmar'

WP 04-07 Nieves Pérez-Solózano-Borragán and Stijn Smismans, 'The European Economic and Social Committee after Enlargement'

WP 03-07 Terrell Carver, 'Sex, Gender and Heteronormativity: Seeing "Some like it Hot” as a Hetersexual Dystopia'

WP 02-07 Eric Herring, 'Neoliberalism versus Peacebuilding in Iraq'

WP 01-07 Terrell Carver, 'Materializing the Metaphors of Global Cities: Singapore and Silicon Valley' 
